This is an author produced version of a paper published in Environmental Science and Technology.

This paper has been peer-reviewed but may not include the final publisher proof-corrections or pagination.

Citation for the published paper:

Dan B. Kleja, Satomi Nakata, Ingmar Persson, Jon Petter Gustafsson. (2016) Silver(I) binding properties of organic soil materials are different from those of isolated humic substances. Environmental Science and Technology. Volume: 50, Number: 14, pp 7453-7460. http://dx.doi.org/10.1021/acs.est.6b00970.

Access to the published version may require journal subscription. Published with permission from: American Chemical Society. 


\title{
Silver(I) binding properties of organic soil materials are different from those of isolated humic substances
}

\author{
Dan B. Kleja, ${ }^{*}+\star$, Satomi Nakata, ${ }^{\dagger, \|}$, Ingmar Persson,, , Jon Petter \\ Gustafsson, ${ }^{\dagger \Delta}$
}

${ }^{\dagger}$ Department of Soil and Environment, Swedish University of Agricultural Sciences, P.O. Box 7014, SE-750 07 Uppsala, Sweden,

¥Swedish Geotechnical Institute, Kornhamnstorg 61, SE-111 27 Stockholm, Sweden

"Kyoto Institute of Technology, Matsugasaki Sakyo-ku, Kyoto 606-8585, Japan

${ }^{\S}$ Department of Chemistry and Biotechnology, Swedish University of Agricultural Sciences, P.O.-Box 7015, SE 750 07, Uppsala, Sweden,

${ }^{\Delta}$ Division of Land and Water Resources Engineering, KTH (Royal Institute of Technology), SE10044 Stockholm.

*e-mail: dan.berggren@slu.se, phone: +46-18-672469, fax: +46-18-673156 


\begin{abstract}
The solubility of silver(I) in many soils is controlled by complexation reactions with organic matter. In this work we have compared the ability of isolated humic and fulvic acids to bind silver(I) with that of mor and peat materials. One new data set for Suwannee River Fulvic Acid was produced, which was consistent with published data sets for isolated fulvic and humic acids. The ability of soil materials to bind silver(I) was studied as a function of $\mathrm{pH}$ in the range 2.5-5.0, at a wide range of silver(I)-to-soil ratios $\left(10^{-4.2}-10^{-1.9} \mathrm{~mol} \mathrm{~kg}^{-1}\right)$. By calibrating the Stockholm Humic Model on the humic and fulvic acids data sets, we showed that binding of silver(I) to both types of soil materials was much stronger (up to two orders of magnitudes) than predicted from the silver(I) binding properties of the isolated humic materials. Thus, the approach taken for many other metals, i.e. to model solubility in soils by using metal and proton binding parameters derived from isolated humic and fulvic acids, cannot be used for silver(I). One possible explanation for the discrepancy could be that silver(I) predominately interacted with various biomolecules in the soil samples, instead of humic- and fulvic-acid type materials.
\end{abstract}

\title{
INTRODUCTION
}

The release of silver (Ag) to the environment from various consumer products and industrial activities is of great concern due to its high toxicity to many soil, sediment and water living organisms. ${ }^{1,2,3,4}$ Silver has historically been released from local point sources, such as abandoned tailings and dams originating from present and past mining activities. ${ }^{5} \mathrm{~A}$ more recent concern is the exposure from wastewater treatment plants, predominantly via land application of biosolids to soils. ${ }^{6}$ During the last decades the number of consumer products containing Ag, mainly as nano-sized metallic silver particles, as an antimicrobial agent has increased drastically. Consumer products, such as plastics and textiles impregnated with engineered silver nanoparticles (AgNPs), might leach silver(I) and AgNPs in contact with water during washing, ${ }^{7,8}$ finally ending up in the sewage sludge ${ }^{6}$, mostly as silver sulfide $\left(\operatorname{Ag}_{2} \mathrm{~S}\right)^{9}$.

The chemistry of silver(I) and AgNPs in soils is very complex, due to redox transformations between the silver(I) and silver(0) forms, and to the ability of silver(I) to strongly interact with 
various organic and mineral surfaces. The strong binding of Ag in soils was shown in a longterm sludge amendment experiment with an agricultural soil, where only $20 \%$ of added silver was leached or removed by crops during a 15 -year period..$^{10}$ However, the major retention mechanisms of silver in soils are still unclear. Silver(I) can be bound by iron (hydr)oxides ${ }^{11}$ and manganese oxides ${ }^{12}$ at higher $\mathrm{pH}$ values $(\mathrm{pH}>4)$, and experiments with isolated humic and fulvic acids showed that these compounds can form strong complexes with silver(I). ${ }^{13,14}$ Sorption experiments performed with "whole" soil materials have shown that silver(I) is sorbed more strongly to soils with high organic matter concentrations than to mineral soils. ${ }^{15}$ The strong interaction with natural organic matter (NOM) was confirmed in a study with silver(I)-spiked soils using Ag K-edge XANES spectroscopy. ${ }^{16}$ The latter study also showed that a significant fraction of silver(I) can be reduced to silver(0) in long-term (6 months) incubations. The reverse reaction might occur under oxidizing conditions, as illustrated by experiments where AgNPs were oxidized to silver(I) in short term (4-48 h) batch experiments with soil materials. ${ }^{17,18}$

The important role of NOM in the binding of silver(I) in soils highlights the need to be able to qualitatively and quantitatively describe this process. During the last decades there has been a continuous development of geochemical models able to describe trace metal binding by NOM; the most common ones being WHAM,${ }^{19}$ NICA-Donnan, ${ }^{20}$ and the Stockholm Humic Model (SHM). ${ }^{21}$ When applying these models on soil systems, a basic assumption is that NOM will behave as isolated humic and fulvic acids in terms of proton and metal binding, i.e. generic values for proton and metal binding constants have been derived from calibration of these models on isolated fulvic and humic acids ${ }^{21}$. This approach has proven to be successful for a range of metal ions, such as $\mathrm{Al}^{3+}, \mathrm{Fe}^{3+}, \mathrm{Cu}^{2+}, \mathrm{Zn}^{2+}$ and $\mathrm{Cd}^{2+}, 22-26$ but has not yet been tested for $\mathrm{Ag}^{+}$. Furthermore, there are just a few published data sets available for silver(I) binding by humic and fulvic acids. ${ }^{13,14}$ The objectives of this study were to (i) produce a consistent dataset for silver(I) binding by a standard fulvic acid (IHSS, Suwannee River Fulvic Acid), (ii) calibrate the SHM model on existing silver(I) binding data sets performed with humic and fulvic acids, (iii) use the calibrated SHM model to predict experimental silver(I) binding data obtained with two organic soil materials (mor and peat), and (iv) to identify possible sites on the organic soil 
materials involved in the binding of silver(I) using silver and sulfur K-edge XANES spectroscopy.

\section{MATERIAL AND METHODS}

Samples. Silver-binding properties of the IHSS Suwannee River fulvic acid I (SRFA) standard (see http://www.humicsubstances.org), and two organic soil samples were investigated in this study. The elemental composition of the SRFA was $52.44 \% \mathrm{C}, 42.20 \% \mathrm{O}, 4.31 \% \mathrm{H}, 0.72 \% \mathrm{~N}$ and $0.44 \% \mathrm{~S}$, the charge density of carboxyl groups at $\mathrm{pH} 8.0$ was estimated to 11.4 meq $(\mathrm{g} \mathrm{C})^{-1}$, and the amino acid content to $24 \mu \mathrm{mol} \mathrm{g}^{-1}$ (Table S1). The two soil samples, one mor (Oe horizon) and one peat sample, were sampled from an Albic Podzol and a Fibric Histosol, ${ }^{27}$ respectively, at Risbergshöjden in central Sweden. The mor sample has been described and used in a number of earlier investigations. ${ }^{25,26}$ After sampling, samples were sieved through a $4 \mathrm{~mm}$ sieve to remove roots and course particles, and then stored in a field moist state at $+4{ }^{\circ} \mathrm{C}$ until further use. The $\mathrm{pH}$ was measured in water extracts (liquid-to-solid ratio 10:1) using a combined glass electrode (PHM 210, Meter Lab). Exchangeable $\mathrm{Na}^{+}, \mathrm{K}^{+}, \mathrm{Ca}^{2+}$ and $\mathrm{Mg}^{2+}$ ions were determined by extraction with $0.1 \mathrm{M} \mathrm{BaCl}_{2}$ following analysis by inductively coupled plasma mass spectrometry (Perkin Elmer ELAN 6100 DRC). By use of $0.1 \mathrm{M} \mathrm{HNO}_{3}$ (1 g dry soil to 30 $\mathrm{mL}$, shaking time $16 \mathrm{~h}$ ), geochemically active concentrations of $\mathrm{Al}$ and $\mathrm{Fe}$ were determined after filtration through a $0.2 \mu \mathrm{m}$ Acrodisc PF filter (Gelman Sciences) and analysis with inductively coupled plasma atomic emission spectroscopy (Jobin-Yvon JY24 ICP). Elemental analysis of N, $\mathrm{C}$, and S in soil samples was performed by Mikro Kemi AB, Sweden (www.mikrokemi.se). Detailed chemical characteristics of the soil materials are given in Table S1.

Potentiometric titrations of SRFA. All chemicals used were analytical grade and Milli-Q water was used throughout the experiments. Potentiometric titrations of SRFA were performed in order to investigate the silver(I) binding as a function of silver(I) to SRFA ratio at $\mathrm{pH} 4.0$ and 8.0. An ion-selective silver electrode (9416SC, Orion) combined with TIM 960 Titration Manager and TitraMaster 85 software (RadiometerAnalytical, 2007) was used in all titrations. A $20 \mathrm{~mL}$ aliquot of $10^{-4} \mathrm{M} \mathrm{AgNO}_{3}$ dissolved in $50 \mathrm{mM} \mathrm{NaNO}_{3}$ was titrated with either $2 \mathrm{~g} \mathrm{~L}^{-1}$ or $4 \mathrm{~g} \mathrm{~L}^{-1}$ of SRFA solution in a $\mathrm{CO}_{2}$-free $\mathrm{N}_{2} / \mathrm{O}_{2}$ (air) atmosphere. The SRFA solutions contained $50 \mathrm{mM}$ 
$\mathrm{NaNO}_{3}$ as supporting electrolyte and adjusted to $\mathrm{pH} 4.0$ or 8.0 prior to titrations by additions of $0.1 \mathrm{M}$ or $0.01 \mathrm{M} \mathrm{NaOH}$ using TIM 960. After each addition of SRFA, the $\mathrm{pH}$ was adjusted automatically to the desired $\mathrm{pH} \pm 0.001$. All titrations were carried out at $+22{ }^{\circ} \mathrm{C}$ in complete darkness. The surface of the electrode was polished gently by fine sandpaper before the experiments in order to remove any possible precipitates that would interfere with analyses. Prior to each titration experiment, the electrode was calibrated on $\mathrm{AgNO}_{3}$ standard solutions in the concentration range $10^{-4}-10^{-2} \mathrm{M}$, using a background of $50 \mathrm{mM} \mathrm{NaNO}_{3}$. A linear Nernstian response of the electrode down to $10^{-8} \mathrm{M}$ free silver(I) concentration was verified by titrations of $10^{-4} \mathrm{M} \mathrm{AgNO}_{3} / 5$ mM EDTA systems (pH 5-10).

Batch experiments with soil materials. In a first set of batch experiments the binding of silver(I) by mor and peat materials was studied as a function of $\mathrm{pH}$ in the range 2.5 to 5.0 at a constant silver(I) concentration $(10.0 \mu \mathrm{M})$. Either $2.0 \mathrm{~g}$ (peat) or $1.0 \mathrm{~g}$ (mor) field moist material was added to $30 \mathrm{~mL}$ solution, which corresponded to 0.20 or $0.45 \mathrm{~g}$ dry material, respectively. Added solutions contained $10.0 \mu \mathrm{M} \mathrm{AgNO} 3$ and appropriate concentrations of $\mathrm{NaNO}_{3}, \mathrm{HNO}_{3}$ and $\mathrm{NaOH}$ in order to achieve the targeted $\mathrm{pH}$ values, while keeping the nitrate concentration constant (10 mM). The samples were equilibrated on an end-over-end shaker (Heidolph Reax II) in darkness at $14{ }^{\circ} \mathrm{C}$ for 48 hours. According to previous studies made with soil materials $\mathrm{s}^{15,17,18}$ and isolated humic fractions ${ }^{28}$, this would enable equilibration of silver(I) ions in the soil suspensions. Long equilibration times (weeks-months), might result in ageing and transformation reactions ${ }^{15,16}$. After equilibration, the samples were centrifuged and filtered through a $0.2 \mu \mathrm{m}$ Acrodisc PF filter (Gelman Sciences). Recovery tests with silver(I)-spiked $\left(10^{-8}-10^{-5} \mathrm{M}\right)$ equilibrium extracts indicated low sorption by these membranes at the experimental conditions used (Table S2). The $\mathrm{pH}$ was measured on the unfiltered supernatants at $14{ }^{\circ} \mathrm{C}$, using a pH M210 standard pH meter (MeterLab) equipped with a combination electrode. Filtered samples were divided in two subsamples. One subsample was acidified $\left(1 \% \mathrm{HNO}_{3}\right)$ and analyzed for silver and major cations $(\mathrm{Ca}, \mathrm{Mg}, \mathrm{K}, \mathrm{Fe}$ and $\mathrm{Al})$ using an inductively coupled plasma sector field mass spectrometer (ICP-SFMS Thermo-Scientific instrument). In the second subsample, dissolved organic carbon (DOC) was determined using a TOC-5000a Analyzer (Shimadzu Corp.). 
In a second set of batch experiments, the silver(I) binding to the mor and peat materials was studied as function of silver loading at two different $\mathrm{pH}$ values, $\mathrm{pH} 2.5$ and $\mathrm{pH} 4.0$, with or without the addition of aluminum(III) or iron(III). The following silver(I) concentrations (as $\mathrm{AgNO}_{3}$ ) were used: $1.0,3.0,10,30$ and $100 \mu \mathrm{M}$, corresponding to an $\mathrm{Ag}(\mathrm{I})$-to-soil ratio of $6.7 \times 10^{-5}-6.7 \times 10^{-3} \mathrm{~mol} \mathrm{Ag} \mathrm{kg}{ }^{-1}$ for the mor sample and $1.5 \times 10^{-4}-1.5 \times 10^{-2} \mathrm{~mol} \mathrm{Ag} \mathrm{kg}^{-1}$ for the peat sample. The ionic strength was held approximately constant at $0.01 \mathrm{M}$, by adding appropriate concentrations of $\mathrm{NaNO}_{3}$ and $\mathrm{HNO}_{3}$, as described above. In the aluminum(III) and iron(III) competition experiments, $1.0 \mathrm{mM} \mathrm{Al}\left(\mathrm{NO}_{3}\right)_{3}$ or $1.0 \mathrm{mM} \mathrm{Fe}\left(\mathrm{NO}_{3}\right)_{3}$ solutions were added to the suspensions. These additions were small enough not to result in precipitation of $\mathrm{Al}(\mathrm{III})$ and Fe(III) (hydr)oxides, as evidenced from geochemical modelling (c.f. below). The samples were equilibrated, treated and analyzed according to the procedure described above. All batch experiments were performed in duplicate.

X-ray absorption spectroscopy. The coordination chemistry of Ag bound by the mor and peat samples was analyzed using X-ray absorption near edge structure (XANES) spectroscopy. Samples were prepared by equilibrating the samples with $100 \mu \mathrm{M} \mathrm{AgNO} 3$ at $\mathrm{pH} 4.0$ according to the procedure described above. Following centrifugation and removal of the supernatant, excess water was removed by either freeze-drying (HETOSICC freeze Dryer Type CD12) or by membrane filtration $(0.45 \mu \mathrm{m})$. Silver K-edge X-ray absorption spectra were recorded at the wiggler beam line 4-1 at the Stanford Synchrotron Radiation Laboratory (SSRL) Stanford, USA, which operated at $3.0 \mathrm{GeV}$ and a current of $250 \mathrm{~mA}$ (top-up mode). The EXAFS station was equipped with a Si[220] double crystal monochromator. Higher order harmonics were reduced by detuning the second monochromator crystal to reflect $80 \%$ of maximum intensity at the end of the scans. The measurements were performed in fluorescence mode using a 13 element solid state Ge detector, and the spectrum of a metallic silver foil was recorded simultaneously in transmission mode as reference; the first inflection point of metallic silver was defined as $25515.0 \mathrm{eV} .{ }^{29}$ The primary data treatment including averaging of the six scans run per sample were performed by means of the EXAFSPAK program package. ${ }^{30}$ The XANES spectra were normalized to an edge step of unity. The spectra were compared with normalized XANES spectra of hydrated, dimethylsulfoxide solvated, ammonia solvated (in aqueous ammonia) and 
$N, N$-dimethylthioformamide solvated silver(I) ions from reported studies, ${ }^{31-33}$ representing $\mathrm{O}, \mathrm{S}$, and $\mathrm{N}$ donor ligands, respectively. The contribution of the different end-members to sample spectra was obtained using an Excel-based linear-combination fitting procedure.

Sulfur K-edge XANES spectra were recorded in the energy range 2422-2622 eV at the wiggler beam-line I811 at MAX-lab, Lund University, Lund, Sweden, equipped with a Si[111] doublecrystal monochromator. The MAX II ring operated at $1.5 \mathrm{GeV}$ and a maximum current of 220 $\mathrm{mA}$. The entire experimental set-up was placed in an arrangement where the beam, formed fluorescence radiation, sample compartment and detector were in a helium atmosphere with a slight over-pressure to minimize leakage of air into the experiment; absorption and scattering of air, also at very low concentrations, cause a large increase in the noise level of the fluorescence signal. The data collection was performed in fluorescence mode at ambient room temperature The fluorescence detection was performed with a PIPS (passivated implanted planar silicon) detector. ${ }^{34}$ It was placed perpendicular to the X-ray beam, and the sample at $45^{\circ}$ relative to the incoming X-ray beam. Higher-order harmonics were reduced by detuning the second monochromator to $20 \%$ of maximum intensity at the end of the scans. Sulfur K-edge spectra of solid sodium thiosulfate pentahydrate, $\mathrm{Na}_{2} \mathrm{~S}_{2} \mathrm{O}_{3} \cdot 5 \mathrm{H}_{2} \mathrm{O}$ (Aldrich), were recorded immediately before or after every sample, assigning the maximum of the first peak in the spectrum to 2472.02 $\mathrm{eV} .{ }^{35}$ The relative concentration of sulfur species in the studied soil samples were determined by linear combination fitting the experimental sulfur $K$-edge XANES data with sulfur model compounds using Microsoft Excel ${ }^{\circledR}$ as described elsewhere. ${ }^{36}$

Geochemical model. The geochemical software Visual MINTEQ ver. 3.1 ${ }^{37}$ was used as the modeling environment for silver(I) speciation. This software contains data for a large number of inorganic complexes in solution involving silver(I), and most of these are from the NIST Critical Stability constants compilation. ${ }^{38}$ To describe the binding of silver(I) to fulvic and humic acids in the aqueous and soil suspensions, the SHM was used, ${ }^{21}$ as modified for solid-phase organic matter in soil suspensions. ${ }^{25}$ The SHM is a discrete-site electrostatic model, in many ways similar to WHAM-Model VII model ${ }^{19}$ except that it uses a different electrostatic submodel. The 
model is described in detail elsewhere. ${ }^{26,39}$ The equations describing metal binding through mono- and bidentate complexes are shown in the Supporting Information section. Silver(I) was assumed to react with weak acid-type sites $(\mathrm{ROH})$ forming a monodentate complex according to:

$\mathrm{ROH}+\mathrm{Ag}^{+} \rightleftarrows \mathrm{ROAg}+\mathrm{H}^{+} \quad ; \quad K_{\mathrm{Ag}}$

where $K_{\mathrm{Ag}}$ is an intrinsic complexation constant. Heterogeneous site affinity of metals is accounted for by a term $\Delta L K_{2}$

$\log K_{\mathrm{Ag}, x}=\log K_{\mathrm{Ag}}+x \cdot \Delta \mathrm{LK}_{2}, x=0,1,2$

where $x=0$ for $90.1 \%, x=1$ for $9 \%$ and $x=2$ for $0.9 \%$ of sites.

In the first step, the model was calibrated for isolated fulvic acids (FA) and humic acids (HA), i.e. using our own potentiometric titration on SRFA as well as the published data sets of Sikora and Stevenson ${ }^{13}$ and Chen et al. ${ }^{14}$. In a second step, the model was used to predict the experimental data for the mor and peat soils using the average binding parameters obtained from step one. For the soil suspensions, we optimized the suspension concentration of humic and fulvic acid that was 'active' with respect to proton and cation binding, through the comparison of measured and simulated $\mathrm{pH}$ values for a given addition of acid or base to mor and peat systems with no metals added (Figure $\mathrm{S} 1)^{25}$. For the proton binding parameters, the generic values for the SHM were used. ${ }^{25}$ All other complexation constants were fixed at those obtained during earlier investigations (see Table S3, Supporting Information). In the optimization procedure it was assumed that $75 \%$ of the 'active' solid-phase organic matter consisted of HA, whereas $25 \%$ was FA. ${ }^{25}$ Furthermore, it was assumed that $100 \%$ of the dissolved organic matter in these suspensions was FA. To consider the effect of initially bound metals in the modeling, the input for 'active' aluminum, iron, major cations and trace metals was estimated from extraction with 0.1 M nitric acid (Table S1, Supporting Information). For sodium and nitrate, the total concentrations were calculated from the added amounts. The optimization procedure resulted in $27 \%$ 'active" organic matter in the mor sample and $33 \%$ in the peat sample (assuming an organic $\mathrm{C}$ content of HA and FA acids of 50\%). 


\section{RESULTS AND DISCUSSION}

Silver binding by isolated humic materials. Titrations of the SRFA showed linear sorption isotherms at both $\mathrm{pH}$ values, with approximately ten times stronger binding at $\mathrm{pH} 8$ compared to pH 4 (Figure 1a). The results obtained at both SRFA concentrations were consistent, indicating an accurate electrode performance. The SHM was able describe the silver(I) binding properties of SRFA well (Figure 1a), using the optimized binding parameters reported in Table S4 (Supporting information). The model was also able to fit all the data sets of Sikora and Stevenson ${ }^{13}$ and Chen et al. ${ }^{14}$ (Figure S2). Furthermore, there was a good agreement between all data sets, giving one set of consistent generic binding parameters representing both HA and FA $\left(\log K_{\mathrm{Ag}}=-2.70, \Delta \mathrm{LK}_{2}=1.68\right.$; Table S4). The data set of Chen et al ${ }^{13}$ is particularly interesting because it includes data for free silver(I) activities $<10^{-8}$ and bound silver concentrations $<10^{-3}$ mol kg${ }^{-1}$ humic acid (Figure 1b). Furthermore, this data set is consistent with results obtained for a HA isolated from a humic Gleysol in Switzerland, representing free silver(I) activities down to $10^{-10.40}$.

a)

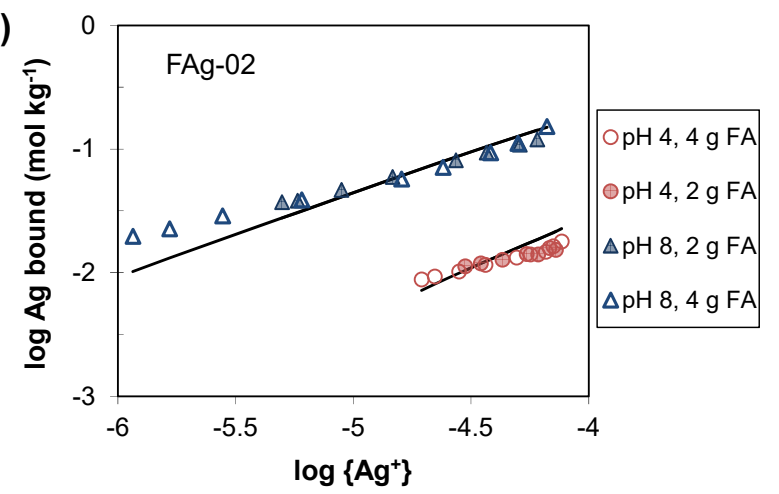

b)

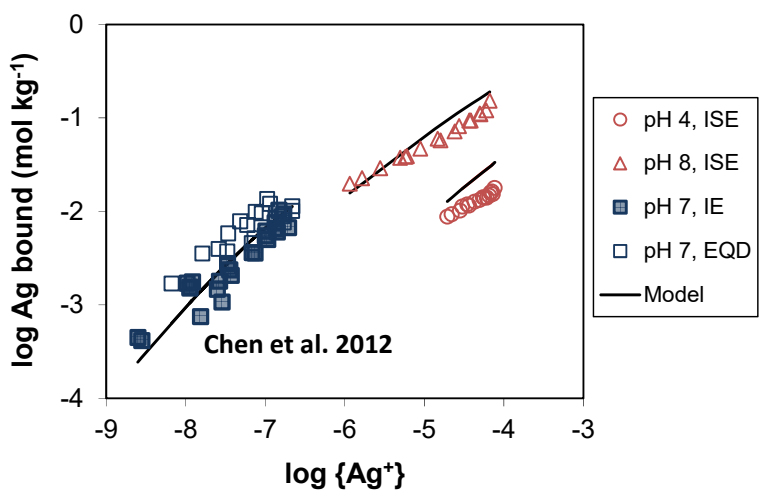

Figure 1. (a) Silver binding isotherms for SRFA obtained by titrating $10^{-4} \mathrm{M} \mathrm{AgNO}_{3}$ with 4.0 or $2.0 \mathrm{~g} \mathrm{~L}^{-1}$ FA solutions at $\mathrm{pH} 4.0$ or 8.0; black line model fit for the SRFA (Table S4), and (b) a comparison of this data with the results from the study by Chen et al. (2012). ISE denotes ion selective electrode, IE is ion exchange equilibrium method and EQD is equilibrium dialysis. The black solid lines are fits obtained with the average binding parameters in Table S4. 
Silver binding by peat and mor samples. As for isolated HA and FA, the mor and peat samples showed a $\mathrm{pH}$ dependent sorption behavior, giving a lower silver solubility with increasing $\mathrm{pH}$ (Figure 2). At the highest $\mathrm{pH}$ values the silver solubility increased again, probably due to the increasing solubility of NOM with increasing $\mathrm{pH}$ (from 14 to $106 \mathrm{mg} \mathrm{L}^{-1}$ in mor suspensions and from 13 to $29 \mathrm{mg} \mathrm{C} \mathrm{L}^{-1}$ in peat suspensions), which favored complexation reactions in the solution phase ${ }^{41}$. The SHM was unable to predict the solubility of silver using the generic binding parameters of HA and FA, giving too high solubility at $\mathrm{pH}<5$. This is in contrast to the results obtained for $\mathrm{Ca}^{2+}, \mathrm{Mg}^{2+}, \mathrm{Al}^{3+}$ and $\mathrm{Fe}^{3+}$, where SHM accurately described the solubility assuming generic binding properties of HA and FA (Figure S3). Thus, silver(I) seems to interact differently with NOM in mor and peat materials from that with isolated HA and FA. The same pattern is observed in the silver(I) binding isotherms made at $\mathrm{pH} 2.5$ and $\mathrm{pH} 4.0$, where the model underestimated silver(I) binding with up to two orders of magnitudes (Figure 3).
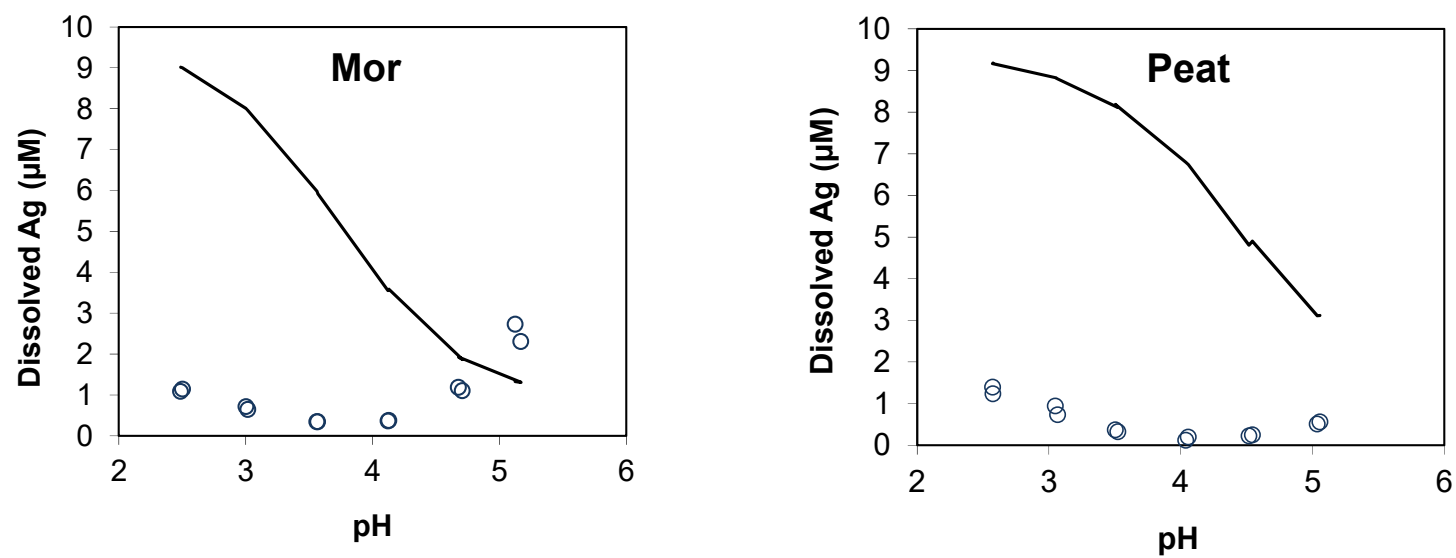

Figure 2. Measured (circles) and modeled (lines) solubility of Ag in the mor and peat suspensions with a total Ag concentration of $10 \mu \mathrm{M}$. Average Ag binding parameters in Table S4 and generic proton and metal binding parameters were used in the simulations.

Furthermore, the experimental data indicated a lack of competition between silver(I) and the trivalent metals iron(III) and aluminum(III), suggesting that the binding of silver(I) occurred to different sites than that of iron(III) and aluminum(III). This is to be expected as silver(I) is regarded as soft electron-pair acceptor according to the concept of hard and soft (Lewis) acids and bases (HSAB) $)^{42-44}$ with preference to form covalent interactions with soft electron-pair 
donors as sulfur and nitrogen donor ligands, while typical hard electron-pair acceptors as iron(III) and aluminum(III) ions form only very weak complexes, if any at all, with such ligands. ${ }^{45}$ At low additions of silver(I) the binding of silver(I) was even higher in the presence of the trivalent metals, an effect that was most pronounced for the mor sample at $\mathrm{pH} 4.0$ (Figure 3 ). The most likely explanation for this phenomenon is the stabilizing effect of the trivalent metals on NOM solubility, as indicated by the decreased DOC concentrations upon addition of aluminum(III) and iron(III) at dissolved silver(I) concentrations $<10^{-6} \mathrm{M}$ (Figure 4a).
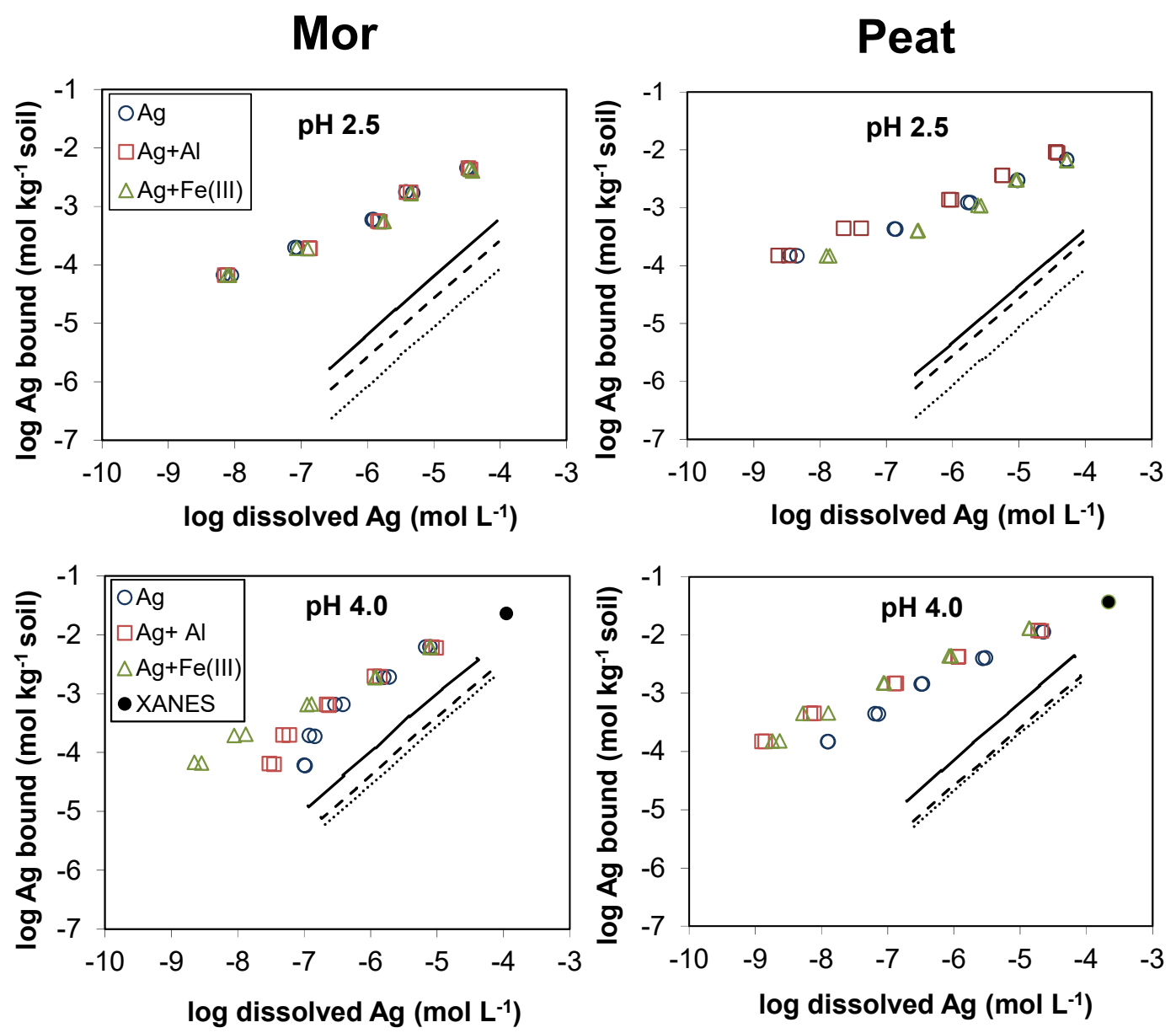

Figure 3. Silver binding isotherms for mor and peat samples obtained at $\mathrm{pH} 2.5$ and 4.0, in suspensions with and without $1000 \mu \mathrm{M}$ iron(III) or aluminum(III). The lines represent model fits using the average binding parameters for silver(I) in Table S4; solid line "only $\mathrm{Ag}^{+}$", dashed line " $\mathrm{Ag}^{+}$plus $\mathrm{Al}(\mathrm{III})$ ", dotted line " $\mathrm{Ag}^{+}$plus Fe(III)". 

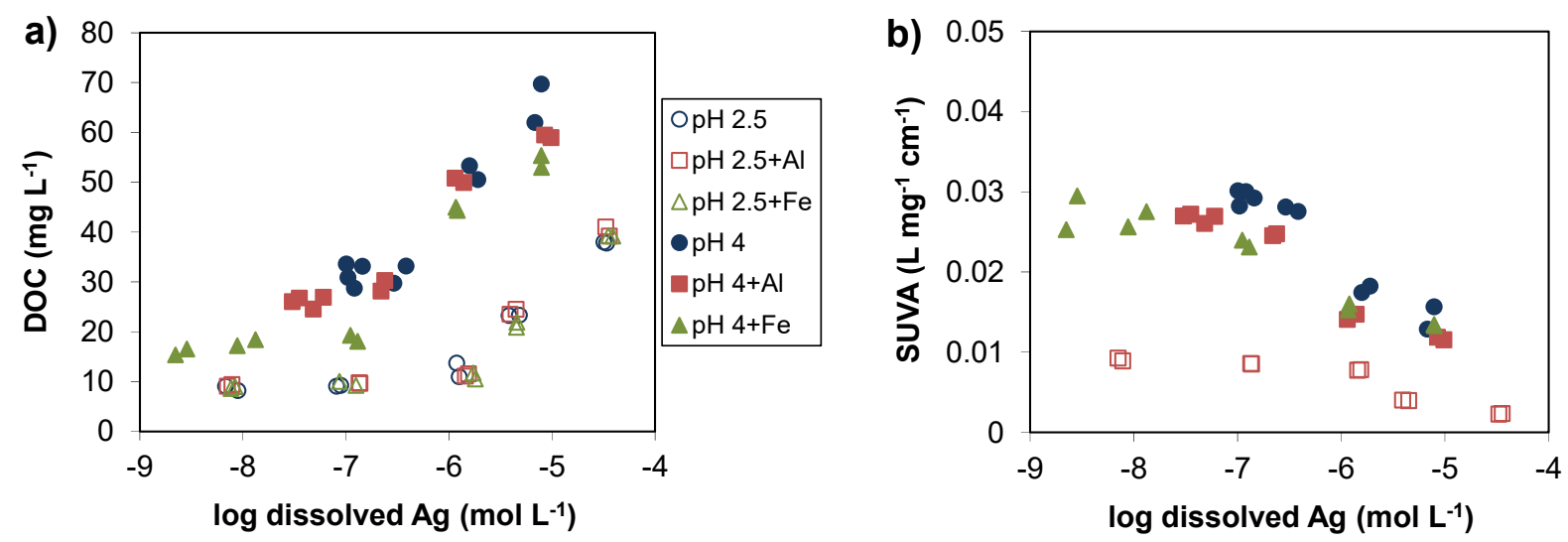

Figure 4. Concentrations of DOC and specific UV absorbance at $254 \mathrm{~nm}$ (SUVA) in the silver binding experiments with the mor sample at $\mathrm{pH} 2.5$ and 4.0, in suspensions with and without $1000 \mu \mathrm{M}$ aluminum(III) or iron(III).

Since dissolved NOM has shown to form very strong complexes with silver(I $)^{46}$ this would promote the solubility of silver(I). The lack of competition between silver(I) and the trivalent cations observed in our study is in contrast to results obtained for $\mathrm{Cd}^{2+}, \mathrm{Co}^{2+}, \mathrm{Ni}^{2+}$ and $\mathrm{VO}^{2+}$ in a previous study with mor sample from Risbergshöjden, showing significant competition between these metals and both iron(III) and aluminum(III). ${ }^{26}$ This could be explained by the fact that the transition metal ions have complex formation properties between typically hard and soft electron-pair acceptors. ${ }^{42-45}$

Although we do not claim that silver(I) binding by isolated HA and FA is correctly described with the SHM, the approach taken certainly shows that the silver(I) binding properties of these compounds differ from those of the two soil materials. One possible explanation for the stronger binding (compared to humic and fulvic acids) in the soil samples might be that silver(I) was reduced to metallic silver by NOM. The ability of HA and FA to reduce silver(I) to metallic silver under reducing conditions ${ }^{40}$ or under oxidizing condition in the presence of light ${ }^{28,47}$ have recently been demonstrated. Indeed, Settimo et al. ${ }^{16}$ found that a significant fraction of silver(I) was reduced to metallic silver following 6 months of incubation at room temperature. However, 
our experiment was performed under oxic conditions in darkness during $48 \mathrm{~h}$, making reduction unlikely. This was also confirmed by the silver K-edge XANES spectra of the two soil samples, which could be fitted with silver(I) coordination (Figure 5).

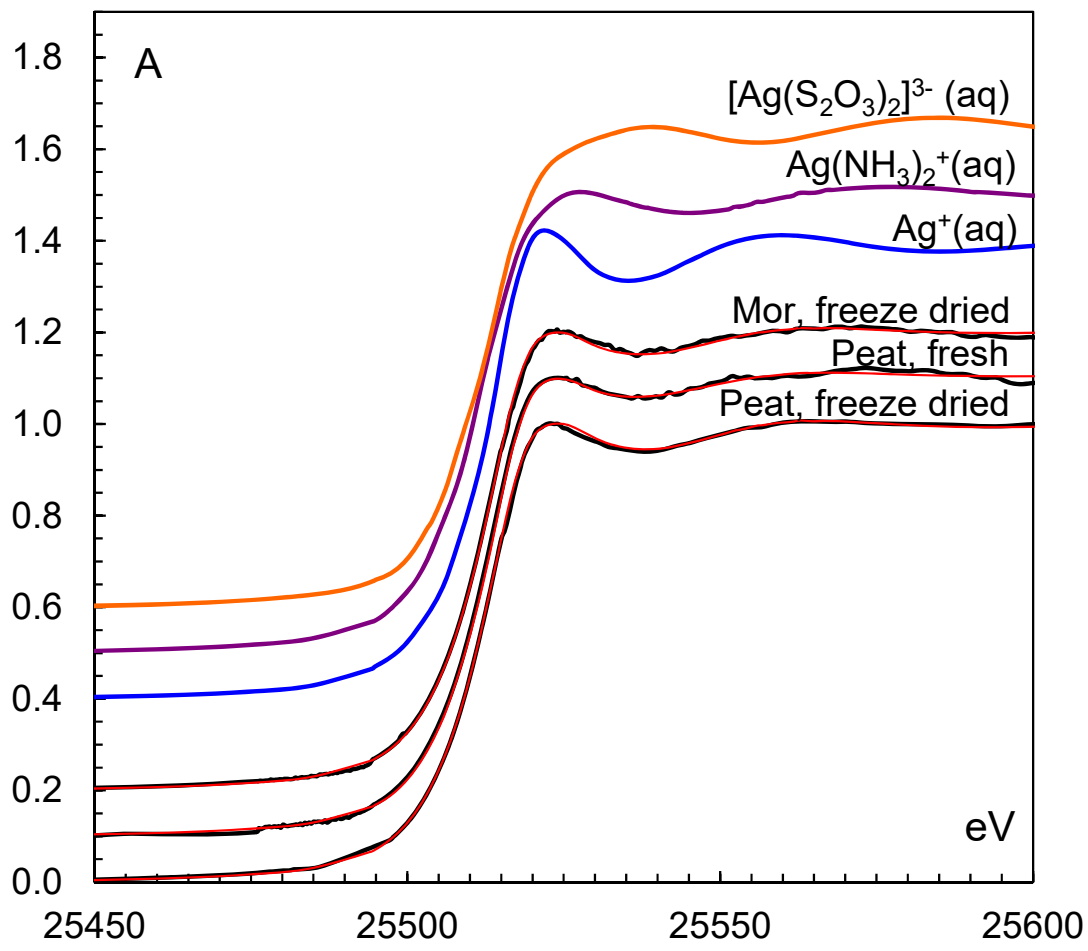

Figure 5. Silver K-edge XANES spectra of mor (freeze dried) and peat samples (fresh and freeze dried); black solid line. Experimental condition for mor sample $0.023 \mathrm{~mol} \mathrm{Al} \mathrm{kg}{ }^{-1}$ soil, and for peat sample $0.037 \mathrm{~mol} \mathrm{Al} \mathrm{kg}^{-1}$ soil. The spectra of hydrated $\mathrm{Ag}^{+}$, ammonia solvated $\mathrm{Ag}^{+}$, and $\mathrm{Ag}(\mathrm{I})$ thiosulfate complex are given as references (refs). The red solid lines represent modeled spectra assuming $50 \% \mathrm{O}$ and $50 \% \mathrm{~N}$ contribution.

According to Maurer et $\mathrm{al}^{40}$, the high silver(I)-to-soil ratios used in the XANES experiment (Figure 3) should have favored reduction of silver(I), rather than the opposite. Another more likely explanation for the strong binding in the mor and peat samples is the presence of functional groups in these samples with very high affinity for silver(I), not being present in the isolated FA and HA materials evaluated. Complex formation studies have shown that silver(I) forms very stable complexes with thiolates, while complexes with sulfides (thioethers) and 
disulfides are significantly weaker (Figure S4). Stability constants ( $\log K)$ for silver(I) thiolate complexes range between 7.0 and 13.0, and silver(I) thioether complexes between 0.5 and 3.9 (Table S5). No stability constants for disulfides were found, indicating very low affinity for silver(I) by this type of groups. Sulfur K-edge XANES data indicated that a small fraction of the sulfur content, ca. $1 \%$, consisted of thiol groups in the mor and peat samples, while these were missing in the SRFA sample (Table 1). The presence of thiol sites were also indicated by the strong binding preference for silver(I) relative to iron(III) and aluminum(III) in the two soil samples (Figure 3). On the other hand, the Ag K-edge XANES spectra for the mor and peat samples indicated no significant contribution from sulfur donor ligands. Instead, the spectra could best be fitted by combining the XANES spectra of hydrated and ammonia solvated silver(I) ions, indicating that silver(I) ions on average bind to one oxygen and one nitrogen donor ligand in an approximately linear fashion. The lack of contribution from sulfur donor ligands in the Ag K-edge XANES spectra are likely due to the fact that the measurements were made at a higher $\operatorname{Ag}(\mathrm{I})$ concentrations than were used in the binding isotherm experiment (Figure 3), due to a limited sensitivity of the XANES method for Ag. Assuming that thiolates constitute $1 \%$ of the total sulfur content (Table 1) gives a maximum contribution of $2 \%$ to the total binding of silver(I) in the silver K-Edge XANES experiment, which is too low fraction to be accurately modeled.

Our silver binding data for SRFA as well as the evaluation of data from other studies on FA and HA isolated from both aquatic systems ${ }^{13,14}$ and soils ${ }^{13,40}$ suggest that the high affinity sites for silver(I) were significantly stronger in the intact soil materials than in the isolated humic materials. One possible explanation could be that thiol groups associated with natural humic materials are being oxidized during the isolation procedure, another that thiol groups mainly are associated with the "non-humic" component of the soil. A substantial body of evidence shows that silver(I) interacts strongly with various biomolecules. Silver can interact with cell walls of living or dead soil organisms such as bacteria ${ }^{48}$ and fungi. ${ }^{49}$ The strong antimicrobial effect of silver(I) is well documented, e.g. silver(I) was the most toxic one among 12 tested metals with respect to soil respiration. ${ }^{1}$ An indication of microbial interaction with silver(I) in our study is given by the increase in DOC concentrations at the two highest additions of silver(I), i.e. 30 and 
$100 \mu \mathrm{M}$ (Figure 4a and Figure S3). The increase is accompanied by a corresponding decrease in specific UV absorbance (Figure 4b and Figure S6), indicating release of hydrophilic, aliphatic organic compounds following lysis of bacterial cells. ${ }^{50}$ In a recent study, Bovenkamp et al. ${ }^{48}$ used silver L3-edge XANES spectroscopy to show that silver(I) did react with bacterial cells, either via Ag-S, Ag-N or a mixed Ag-N and Ag-O binding. The dominant binding mechanism was to nitrogen groups or to a combination of nitrogen and oxygen groups, possibly associated with amine and carboxyl groups of peptidoglycan in cell walls. The low contribution of the Ag-S interaction was explained by the fact that S-containing amino acids are present only in low concentrations in the bacterial cell walls. Measurements on model systems where silver(I) was added to solutions containing a mixture of histidine and cysteine (in a 1:1 ratio) showed that only silver(I) cysteine complexes were formed ${ }^{48}$, illustrating that silver(I) bonds first to thiol groups if available, and only then bonds to nitrogen and oxygen donor groups.

Table 1. Speciation of sulfur compounds in mor, peat and SRFA samples using sulfur $K$ edge XANES spectroscopy. Calibration was made according to the procedure described in Almkvist et al. $^{34}$. Spectra and model fits are shown in Figure S4. Fresh samples were analyzed field moist and dried samples were dried at room temperature (c. $\left.22^{\circ} \mathrm{C}\right)$ prior to analysis.

\begin{tabular}{|c|c|c|c|c|c|c|}
\hline \multirow[t]{2}{*}{ Model compound } & \multirow[t]{2}{*}{ Function } & Peat dried & Peat fresh & Mor dried & Mor fresh & SRFA \\
\hline & & \multicolumn{5}{|c|}{ — $\%$ distribution- } \\
\hline L-Cysteine & thiol & 1 & 2 & 1 & 1 & 0 \\
\hline L-Cystine & disulfide & 15 & 17 & 14 & 15 & 7 \\
\hline L-Methionine & thioether & 0 & 0 & 0 & 0 & 6 \\
\hline Diphenyl sulfide & thioether & 11 & 11 & 23 & 22 & 32 \\
\hline Dimethylsulfoxide & sulfoxide & 4 & 4 & 10 & 10 & 3 \\
\hline Sulfolane & sulfone & 2 & 2 & 6 & 6 & 0 \\
\hline Methylsulfonate & sulfonate & 1 & 5 & 3 & 3 & 11 \\
\hline Chondroitin sulfate ester & sulfate ester & 49 & 37 & 40 & 40 & 40 \\
\hline Sodium sulfate decahydrate & sulfate & 18 & 22 & 3 & 4 & 0 \\
\hline
\end{tabular}


Environmental implications. Care should be taken when applying geochemical models like WHAM, NICA-Donnan, and SHM, calibrated on data sets for isolated HA and FA, when predicting the solubility of silver(I) in soils. The ability to make accurate predictions of the free metal ion concentration in the soil solution is crucial when applying bioavailability-based terrestrial toxicity models like the Terrestrial Biotic Ligand Model (TBLM) ${ }^{51}$ and the WHAM$F_{\text {TOX }}$ model $^{52,53}$, because the toxic effect is related to the free metal ion activity. Hence, more research is needed to elucidate the binding mechanisms of silver(I) to soil organic matter, and the role of different organic compounds, including living microorganisms, in the binding of silver(I).

\section{ASSOCIATED CONTENT}

\section{Supporting information}

Equations describing metal complexation in the Stockholm Humic model, physicochemical characteristics of Suwannee River Fulvic Acid and soil samples (Table S1), test of membrane filters (Table S2), metal complexation in the Stockholm Humic Model (Table S3), data sets and optimized silver(I) binding parameters for isolated humic and fulvic acids (Table S4), a compilation of equilibrium constants for $\mathrm{S}$ and $\mathrm{N}$ donor ligands (Table S5), acid-base titration curves for the mor and peat samples (Figure S1), experimental data and SHM fits for isolated fulvic and humic acids (Figure S2), experimental data and SHM fits for $\mathrm{Ca}, \mathrm{Mg}, \mathrm{Fe}$ and $\mathrm{Al}$ in the mor and peat suspensions (Figure S3), conditional constants for silver(I) binding by cysteine, dimethylsulfide and alanine (Figure S4), measured and modeled sulfur $K$-edge XANES spectra mor, peat and Suwannee River Fulvic Acid samples (Figure S5), DOC concentrations and specific UV absorbance in peat extracts (Figure S6).

\section{ACKNOWLEDGMENTS}

The study was founded by the Swedish Research Council (Vetenskapsrådet) (number 2008-4354). We gratefully acknowledge Stanford Synchrotron Radiation Laboratory (SSRL) and MAX-lab, Lund University, for the allocation of beam time and laboratory facilities. Use of the Stanford Synchrotron Radiation Lightsource, SLAC National Accelerator Laboratory, is supported by the U.S. Department of Energy, Office of Science, Office of Basic Energy Sciences under Contract No. DE-AC02-76SF00515. 
The SSRL Structural Molecular Biology Program is supported by the DOE Office of Biological and Environmental Research, and by the National Institutes of Health, National Institute of General Medical Sciences (including P41GM103393). The contents of this publication are solely the responsibility of the authors and do not necessarily represent the official views of NIGMS or NIH. MAX-lab is supported by the Swedish Research Council and The Knut and Alice Wallenberg Foundation, with additional support from The Crafoord Foundation and The Faculty of Science and Technology, Norwegian University of Science and Technology.

\section{REFERENCES}

(1) Cornfield A.H. Effects of addition 12 metals on carbon dioxide release during incubation of an acid sandy soil. Geoderma 1977, 19 (3), 199-203.

(2) Berthet B.; Amirad J.C.; Amird-Triquet C.; Martoja M.; Jeantet A.Y.; Bioaccumulation, toxicity, and physico-chemical speciation of silver in bivalve molluscs: Ecotoxicological and health consequences. Sci. Tot. Environ. 1992, 125, 97-122.

(3) Ratte H.T. Bioaccumulation and toxicity of silver compounds: A review. Environ. Toxicol. Chem. 1999, 18 (1), 89-108.

(4) Noredal Throbäck, I.; Johansson, M.; Rosenquist, M.; Pell, M.; Hansson, M.; Hallin, S. Silver $\left(\mathrm{Ag}^{+}\right)$reduces denitrification and induces enrichment of novel nirK genotypes in soil. FEMS Microbiol. Lett. 2007, 270 (2), 189-194.

(5) Candeias, C.; Ávila, P.F.; Ferreira da Silva, E.; Ferreira, A.; Duraes, N.; Teixeira, J.P. Water-rock interaction and geochemical processes in surface waters influenced by tailings impoundments: impact and threats to the ecosystems and human health in rural communities (Panasqueira mine, central Portugal). Water Air Soil Pollut., 2015, 226 (23) 1-30.

(6) Gottschalk F,; Sonderer T.; Scholz, R.W.; Nowack, B. Modeled environmental concentrations of engineered nanomaterials (TiO(2), $\mathrm{ZnO}, \mathrm{Ag}$, CNT, Fullerenes) for different regions. Environ. Sci. Technol. 2009, 43 (24), 9216-9222.

(7) Kumar, R.; Munstedt, H. Silver ion release from antimicrobial polyamide/silver composites. Biomaterials. 2005, 26 (14), 2081-2088.

(8) Benn, T. M.; Westerhoff, P. Nanoparticle silver released into water from commercially available sock fabrics. Environ. Sci. Technol. 2008, 42 (11), 4133-4139.

(9) Kaegi, R.; Voegelin, A.; Sinnet, B.; Zuleeg, S.; Hagendorfer, M.; Burkhardt, M; Siegrist, H. Behavior of metallic silver nanoparticles in a pilot wastewater treatment plant. Environ. Sci. Technol. 2011, 45 (9), 39023908 .

(10) McBride, M.; Richards, B.K.; Steenhuis, T.; Spiers, G. Long-term leaching of trace elements in a heavily sludge-amended silty clay loam soil. Soil Sci. 1999, 164 (9), 613-623.

(11) Dyck, W. Adsorption and coprecipitation of silver on hydrous ferric oxide. Can. J. Chem. 1968, 46 (8), 14411444.

(12) Anderson, B.J.; Jenne, E.A.; Chao, T.T. The sorption of silver by poorly crystallized manganese oxides. Geochim. Cosmochim. Acta 1973, 37 (3), 611- 22

(13) Sikora F.J.; Stevenson, F.J. Silver complexation by humic substances: Conditional stability constants and nature of reactive sites, Geoderma, 42 (3-4), 1988, 353-363. 
(14) Chen, Z.; Campbell, P. G. C.; Fortin C. Silver binding by humic acid as determined by equilibrium ionexchange and dialysis. J. Phys. Chem. A. 2012, 116 (25), 6532-6539.

(15) Jacobsen, A.R.; McBride, M.B.; Baveye, P.; Steehuis, T.S. Environmental factors determining the trace-level sorption of silver and thallium to soils. Sci. Tot. Environ. 2005, 345, 191-205.

(16) Settimio, L.; McLaughlin, M.L.; Kirby, J.K.; Landon, K.A.; Lombi, E: Donner, E; Scheckel, K.G. Fate and lability of silver in soils: Effect of ageing. Environ. Pollut. 2014, 191, 151-157.

(17) Benoit, R.; Wilkinson, K.J.; Sauvé, S. Partitioning of silver and chemical speciation of free Ag in soils amended with nanoparticles. Chem. Cent. J. 2013, 7 (75).

(18) Hedberg, J.; Oromieh, A.G.; Kleja, D.B.; Wallinder, I.O. Sorption and dissolution of bare and coated silver nanoparticles in soil suspensions - Influence of soil and particle characteristics. Journal of Environmental Science and Health, Part A: Toxic/Hazardous Substances and Environmental Engineering, 2015, 50 (9), 891 900.

(19) Tipping, E.; Lofts, S.; Sonke, J.E. Humic ion binding Model VII: a revised parameterisation of cationbinding by humic substances. Environ. Chem. 2011, 8 (3), 225-235.

(20) Kinniburgh, D.G.; van Riemsdijk, W.H.; Koopal, L.K.; Borkovec, M.; Benedetti, M.F.; Avena, M.J. Ion binding to natural organic matter: competition, heterogeneity, stoichiometry, and thermodynamic consistency. Colloid Surf. 1999, A151 (1-2), 147-166.

(21) Gustafsson, J.P. Modeling the acid-base properties and metal complexation of humic substances with the Stockholm Humic Model. J. Colloid Interface Sci. 2001, 244 (1), 102-112.

(22) Tipping, E. Cation binding by humic substances. Cambridge University Press. 2002. 434 pp.

(23) Tipping, E.; Berggren, D.; Mulder, J.; Woof, C. 1995. Modelling the solid-solution distributions of protons, aluminium, base cations and humic substances in acid soils. Eur. J. Soil Sci. 1995, 46 (1), 77-94.

(24) Gustafsson, J.P.; Pechova, P.; Berggren, D. Modeling metal binding to soils: The role of natural organic matter. Environ. Sci. Technol. 2003, 37 (12), 2767-2774.

(25) Gustafsson, J. P.; van Schaik, J. W. J. Cation binding in a mor layer: batch experiments and modelling. Eur. J. Soil Sci. 2003, 54 (2), 295-310.

(26) Gustafsson, J. P.; Persson, I.; Kleja, D. B.; van Schaik, J. W. J. Binding of iron(III) to organic soils: EXAFS spectroscopy and chemical equilibrium modeling. Environ. Sci. Technol. 2007, 41 (4), 1232-1237.

(27) IUSS Working Group WRB, World reference base for soil resources 2014. International soil classification system for naming soils and creating legends for soil maps. World Soil Resources Reports No. 106. FAO, Rome.

(28) Mousavi, M.P.S.; Gunsolus, I.L.; Péres De Jesús, C.E.; Lancaster, M.; Hussein, K.; Haynes, C.L.; Bühlmann, P. Dynamic silver speciation as studied with fluorous-phase ion-selective electrodes: Effect of natural organic matter on the toxicity and speciation of silver. Sci. Total Environ. 2015, 537, 453-461.

(29) Thompson, A.; Attwood, D.; Gullikson, E.; Howells, M.; Kim, K.-J.; Kirz, J., Kortright, J.; Lindau, I.; Pianatta, P.; Robinson, A.; Scofield, J.; Underwood, J.; Vaughan, D.; Williams, G.; Winick, H. 2001 X-ray Data Booklet; LBNL/PUB-490 Rev. 2, Lawrence Berkeley National Laboratory, Berkeley, CA 94720, USA.

(30) George, G. N.; Pickering, I. J., EXAFSPAK - A suite of computer programs for analysis of X-Ray absorption spectra, SSRL, Stanford, CA. 1993.

(31) Persson, I.; Nilsson, K. B. Coordination chemistry of the solvated silver(I) ion in oxygen donor solvents water, dimethyl sulfoxide and N,N'-dimethylpropyleneurea. Inorg. Chem. 2006, 45 (18), 7428-7434.

(32) Nilsson, K. B.; Kessler V. G.; Persson, I. Coordination chemistry of the solvated AgI and AuI ions in liquid and aqueous ammonia, trialkyl and triphenyl phosphite, and tri-n-butylphosphine solutions. Inorg. Chem. 2006, 45 (17), 6912-6021. 
(33) Stålhandske, C.M.V.; Stålhandske, C. I.; Persson, I.; Sandström M.; Jalilehvand, F. Crystal and solution structures of N,N-dimethylthioformamide-solvated copper(I), silver(I), and gold(I) ions studied by X-ray diffraction, X-ray absorption, and vibrational spectroscopy. Inorg. Chem. 2001, 40 (26), 6684-6693.

(34) http://www.canberra.com/products/detectors/pips-detectors.asp

(35) Williams, K. R.; Hedman, B.; Hodgson, K. O.; Solomon, E. I. Ligand K-edge X-ray absorption spectroscopic studies: metal-ligand covalency in transition metal tetrathiolates Inorg. Chim. Acta. 1997. 263 (1-2), 315-321.

(36) Almkvist, G.; Boye, K.; Persson, I. K Edge XANES Analysis of sulfur compounds - An investigation of the relative intensities using internal calibration. J. Synchrotron Rad. 2010, 17, 683-688.

(37) Gustafsson, J. P. Visual MINTEQ version 3.1. Stockholm, Sweden, February 2013.http://www2.lwr.kth.se/English/OurSoftware/vminteq/index.html

(38) Smith, R. M.; Martell, A. E.; Motekaitis, R. J. NIST critically selected stability constants of metal complexes database. Version 7.0. NIST Standard Reference Database 46. National Institute of Standards and Technology, US Department of Commerce: Gaithersburg, VA, 2003.

(39) Gustafsson, J. P.; Kleja, D. B. Modeling salt-dependent proton binding by organic soils with the NICADonnan and Stockholm Humic models. Environ. Sci. Technol. 2005, 39 (14), 5372-5377.

(40) Maurer, F.; Christl, I.; Hoffmann, M.; Kretzschmar, R. Reduction and reoxidation of humic acid: influence on speciation of cadmium and silver. 2012. Environ. Sci. Technol. 2012, 46 (16), 8808-8816.

(41) Gustafsson, J.P.; Persson, I.; Oromieh, A.G.; van Schaik, J.W.J.; Sjöstedt, C.; Kleja, D.B. Chromium(III) complexation to natural organic matter: Mechanisms and modeling. Environ. Sci. Technol. 2014, 48 (3), 1753-1761.

(42) Pearson, R. G. Hard and soft acids and bases, J. Am. Chem. Soc. 1963, 85 (22), 3533-3539.

(43) Pearson, R. G. Hard and soft acids and bases, HSAB, part 1: Fundamental principles, J. Chem. Educ. 1968, 45 (9), 581-586.

(44) Pearson, R G. Hard and soft acids and bases, HSAB, part 1: Underlying theories, J. Chem. Educ. 1968, 45 (10), 643-648.

(45) IUPAC Stability Constants Database (SC-Database), Royal Society of Chemistry, Academic Software, 2000, and references therein.

(46) Herrin, R.T.; Andren, A.W.; Shafer, M.M.; Armstrong, D.E. Determination of silver speciation in natural waters. 2. Binding strength of silver ligands in surface freshwaters. Environ. Sci. Technol. 2001, 35 (10), 1959-1966.

(47) Akaighe, N.; MacCuspie, R.I.; Navarro, D.A.; Aga, D.S.; Banerjee, S.; Sohn, M.; Sharma, V.K. Humic acidinduced silver nanoparticle formation under environmentally relevant conditions. Environ. Sci. Technol. 2011, 45 (9), 3895-3901.

(48) Bovenkamp, G.L., Zanzen, U.,, Krishna, K.S., Hormes, J., Prange, A. The interaction of silver ions with Staphylococcus aureus, Listeria monocytogenes, and Escherichia coli - an X-ray absorption near edge structure (XANES) spectroscopy study. Appl. Environ. Microbiol. 2013, 79 (20), 6385-6390.

(49) Borovička, J.; Kotrba, P.; Gryndler, M.; Mihaljevič, M.; Řanda, Z.; Rohovec, J.; Cajthaml, T.; Stijve, T.; Dunn, C.E. Bioaccumulation of silver in ectomycorrhizal and saprobic macrofungi from pristine and polluted areas. Sci. Tot. Environ. 2010, 408 (13), 2733-2744.

(50) Dilling, J; Kaiser, K. Estimation of the hydrophobic fraction of dissolved organic matter in water samples using UV photometry. Water Res. 2002, 36 (20), 5037-5044.

(51) Thakali, S.; Allen, H. E.; Di Toro, D. M.; Ponizovsky, A.; Rooney, C.R.; Zhao, F.J.; McGrath, S.P. A Terrestrial biotic ligand model. 1. Development and application to $\mathrm{Cu}$ and $\mathrm{Ni}$ toxicities to barley root elongation in soils. Environ. Sci. Technol. 2006, 40 (22), 7085-7093. 
(52) Stockdale, A.; Tipping, E.; Lofts, S.; Ormerod, S. J.; Clements, W. H.; Blust, R. Toxicity of proton-metal mixtures in the field: Linking stream macroinvertebrate species diversity to chemical speciation and bioavailability. Aquat. Toxicol. 2010, 100 (1), 112-119.

(53) Qui, H.; Versieren, L.; Rangel G.G.; Smolders, E. 2015, Interactions and toxicity of Cu-Zn mixtures to Hordeum vulgare in different soils can be rationalized with bioavailability-based prediction models. Environ. Sci. Technol. 2016, 50 (2), 1014-1022

\section{TOC / ABSTRACT ART}

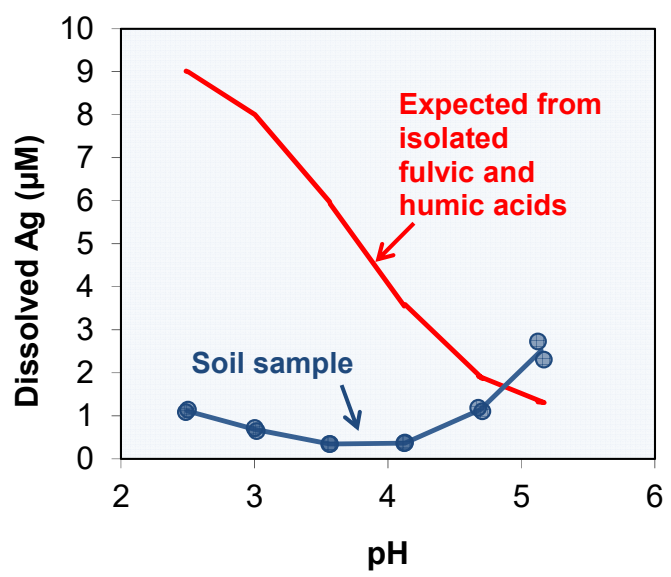




\section{Silver(I) binding properties of organic soil materials are different from those of isolated humic substances}

Dan B. Kleja, Satomi Nakata, Ingmar Persson, Jon Petter Gustafsson

\section{$\underline{\text { Supporting information }}$}

\section{Contents}

Equations describing metal complexation in the Stockholm Humic model (text)

Table S1. Physicochemical characteristics of fulvic acid and soil samples.

Table S2. Recovery of silver(I) added to mor extracts (as AgNO3) during filtration using 0.2 $\mu \mathrm{m}$ Acrodisc PF filters.

Table S3. Cation complexation reactions to soil organic matter in the Stockholm Humic Model

Table S4. Data sets and optimization for silver complexation to humic and fulvic acid in the Stockholm Humic Model

Table S5. A compilation of equilibrium constants for S and $\mathrm{N}$ donor ligands.

Figure S1. Acid-base titration curves for the mor and peat samples.

Figurer S2. Experimental data and SHM fits for isolated fulvic and humic acids.

Figure S3. Measured and modeled solubility of $\mathrm{Ca}, \mathrm{Mg}, \mathrm{Fe}$ and $\mathrm{Al}$ in the mor and peat suspensions.

Figure S4. Conditional constants for silver(I) binding by cysteine (thiol), dimethylsulfide (thioether) and alanine (amine).

Figure S5. Sulfur $K$-edge XANES spectra of peat, mor and IHSS Suwannee River fulvic acid standard samples.

Figure S6. Concentrations of DOC and specific UV absorbance at $254 \mathrm{~nm}$ in the silver binding experiments with the peat sample. 


\section{Equations describing metal complexation in the Stockholm Humic model}

The SHM allows metals to bind as monodentate, bidentate or tridentate complexes. The following reaction shows the formation of a monodentate complex involving a divalent metal ion $\mathrm{M}^{2+}$ :

$\mathrm{ROH}+\mathrm{M}^{2+} \rightleftarrows \mathrm{ROM}^{+}+\mathrm{H}^{+} \quad ; \quad K_{\mathrm{M}, \mathrm{m}}$

The equilibrium constant $K_{\mathrm{M}, \mathrm{m}}$ is defined according to:

$K_{\mathrm{Ca}, \mathrm{m}}=\frac{\left\{\mathrm{ROM}^{+}\right\}\left\{\mathrm{H}^{+}\right\}}{\{\mathrm{ROH}\}\left\{\mathrm{M}^{2+}\right\}} \cdot \exp \left(-g_{f} \cdot \frac{F\left(0.5 \Psi_{o}-1.5 \Psi_{d}\right)}{R T}\right)$

where $g_{\mathrm{f}}$ is the so-called gel-fraction parameter, whereas $F$ is the Faraday constant, $R$ is the gas constant, $T$ is the absolute temperature, and $\Psi_{\mathrm{o}}$ and $\Psi_{\mathrm{d}}$ are electrostatic potentials in the $o$ and $d$-planes, respectively (Gustafsson, 2001). The relative contributions of $o$ - and $d$-plane charge for the complexes considered are shown in Table 1. To account for heterogeneity of site affinity for metal complexation the parameter $\Delta L K_{2}$ is introduced:

$\log K_{\mathrm{M}, \mathrm{m}, \mathrm{x}}=\log K_{\mathrm{M}, \mathrm{m}}+x \cdot \Delta L K_{2}, \quad x=0,1,2$

This allows each site to be subdivided into three subsites with differing affinity for metalhumic complexation; $x$ is set to 0 for $90.1 \%$ of the sites, to 1 for $9 \%$ and to 2 for $0.9 \%$. Monodentate complexes can be formed with proton sites 1, 2, 3, 4, i.e. with the carboxylic acid sites (Gustafsson et al. 2007). When the metal binds to two surface sites, a bidentate complex is formed. For aluminium(III), the reaction is described as follows:

$$
\begin{aligned}
& 2 \mathrm{ROH}+\mathrm{Al}^{3+} \rightleftarrows(\mathrm{RO})_{2} \mathrm{Al}^{+}+2 \mathrm{H}^{+} ; \quad K_{\mathrm{Al}, \mathrm{b}} \\
& K_{\mathrm{Al}, \mathrm{b}}=\frac{\left\{(\mathrm{RO})_{2} \mathrm{Al}^{+}\right\}\left\{\mathrm{H}^{+}\right\}^{2}}{\{\mathrm{ROH}\}^{2}\left\{\mathrm{Al}^{3+}\right\}} \cdot \exp \left(-g_{f} \cdot \frac{F\left(-0.2 \Psi_{o}+1.2 \Psi_{d}\right)}{R T}\right) \cdot S_{b i d} \\
& \log K_{\mathrm{Al}, \mathrm{b}, \mathrm{x}}=\log K_{\mathrm{Al}, \mathrm{b}}+2 x \cdot \Delta L K_{2}, \quad x=0,1,2
\end{aligned}
$$

The extra term $S_{b i d}$ is used to correct the constant for the bidentate coordination (Venema et al., 1996). This correction is done automatically in the Visual MINTEQ software. Bidentate 
complexes may involve both carboxylate and phenolate sites; the combinations of protonbinding sites used in the SHM were detailed in Gustafsson et al. (2007). A bidentate complex similar to that for aluminium(III) was considered also for chromium(III), see Table 1.

Tridentate complexes are defined in a similar fashion, but at present such complexes are used only for chromium(III) (Gustafsson et al. 2014).

\section{References}

Gustafsson, J.P. Modeling the acid-base properties and metal complexation of humic substances with the Stockholm Humic Model. J. Colloid Interface Sci. 2001, 244 (1), 102-112.

Gustafsson, J.P.; Persson, I.; Kleja, D.B.; van Schaik, J.W.J. Binding of iron(III) to organic soils: EXAFS spectroscopy and chemical equilibrium modeling. Environ. Sci. Technol. 2007, 41 (4), 1232-1237.

Gustafsson, J.P., Persson, I., Oromieh, A.G., van Schaik, J.W.J., Sjöstedt, C., Kleja, D.B. Chromium(III) complexation to natural organic matter: mechanisms and modeling. Environ. Sci. Technol. 2014, 48 (3), 1753 1761.

Venema, P., Hiemstra, T., van Riemsdijk, W.H. Multisite adsorption of cadmium on goethite. J. Colloid Interface Sci. 1996, 183, 515-527. 
Table S1. Physicochemical characteristics of fulvic acid and soil samples. Data of 1S101F was obtained from the IHSS (2016).

\begin{tabular}{|c|c|c|c|}
\hline & $\begin{array}{c}\text { Fulvic acid } \\
\text { (1S101F) }\end{array}$ & Mor & Peat \\
\hline Water $(\%)$ & & 57 & 90 \\
\hline $\mathrm{pH}\left(\mathrm{H}_{2} \mathrm{O}\right)$ & & 3.58 & 3.71 \\
\hline \multicolumn{4}{|c|}{$\mathrm{BaCl}_{2}$-Extractable cations $\left(\mathrm{cmol}(+) \mathrm{kg}^{-1}\right)^{*}$} \\
\hline $\mathrm{Na}^{+}$ & & 0.49 & 0.57 \\
\hline $\mathrm{K}^{+}$ & & 0.64 & 1.28 \\
\hline $\mathrm{Ca}^{2+}$ & & 10.4 & 12.0 \\
\hline $\mathrm{Mg}^{2+}$ & & 3.46 & 5.06 \\
\hline \multicolumn{4}{|c|}{$\mathrm{HNO}_{3}$-Extractable $\mathrm{Fe}$ and $\mathrm{Al}\left(\mathrm{mol} \mathrm{kg}^{-1}\right)$} \\
\hline $\mathrm{Fe}^{3+}$ & & 0.0021 & 0.019 \\
\hline $\mathrm{Al}^{3+}$ & & 0.017 & 0.044 \\
\hline \multicolumn{4}{|l|}{ Elemental composition (wt \%) } \\
\hline $\mathrm{C}$ & 52.4 & 49.8 & 45.4 \\
\hline $\mathrm{N}$ & 0.72 & 1.35 & 1.05 \\
\hline $\mathrm{S}$ & 0.44 & 0.11 & 0.18 \\
\hline Total amino acids $\left(\mu \mathrm{mol} \mathrm{g}^{-1}\right)$ & 24 & & \\
\hline Carboxyl groups (meq $\left(\mathrm{g} \mathrm{C}^{-1}\right.$ ) & 11.4 & & \\
\hline \multicolumn{4}{|l|}{ cmol charge per kg soil. } \\
\hline References & & & \\
\hline
\end{tabular}


Table S2. Recovery of $\mathrm{Ag}(\mathrm{I})$ added to mor extracts (as $\mathrm{AgNO}_{3}$ ) during filtration using $0.2 \mu \mathrm{m}$ Acrodisc PF filters (Pall Corporation). Experimental conditions are identical with those in the batch experiments with mor soil. Field moist mor material was equilibrated with pH adjusted $0.01 \mathrm{M} \mathrm{NaNO}_{3}$ solutions at a liquid-to-solid ratio of 30 (L/kg) at $14{ }^{\circ} \mathrm{C}$ during 48 hours. Following centrifugation, extracts were filtered through $0.2 \mu \mathrm{m}$ Supor membranes and then spiked with a range of $\mathrm{AgNO}_{3}$ concentrations (four orders of magnitude), six per concentration. Three of the spiked solutions were acidified to $1 \%$ concentrated $\mathrm{HNO}_{3}$ and analysed without any pre-treatment, whereas the other three solutions were filtered through $0.2 \mu \mathrm{m}$ Acrodisc PF filters prior to acidification and analysis. The concentration of DOC in the $\mathrm{pH} 2.5$ solutions was $10 \mathrm{mg} / \mathrm{L}$ and in the pH 3.7 solutions it was $25 \mathrm{mg} / \mathrm{L}$. Values in table represent mean \pm one standard error $(\mathbf{n}=3)$.

\begin{tabular}{|c|c|c|c|c|}
\hline \multirow[t]{2}{*}{ Sample } & \multirow[t]{2}{*}{ Spike (M) } & \multicolumn{2}{|c|}{ Concentration $(\mu \mathrm{M})$} & \multirow[t]{2}{*}{$\%$ loss } \\
\hline & & Prior to filtration & After filtration & \\
\hline \multirow[t]{4}{*}{ Mor extract, $\mathrm{pH} 2.5$} & $10^{-5}$ & $10.3 \pm 0.03$ & $10.2 \pm 0.06$ & 1 \\
\hline & $10^{-6}$ & $1.14 \pm 0.003$ & $1.13 \pm 0.003$ & 0 \\
\hline & $10^{-7}$ & $0.110 \pm 0.001$ & $0.109 \pm 0.001$ & 1 \\
\hline & $10^{-8}$ & $0.0108 \pm 0.00003$ & $0.0106 \pm 0.00005$ & 2 \\
\hline \multirow[t]{4}{*}{ Mor extract, $\mathrm{pH} 3.7$} & $10^{-5}$ & $9.00 \pm 0.36$ & $7.14 \pm 0.56$ & 21 \\
\hline & $10^{-6}$ & $0.992 \pm 0.005$ & $0.976 \pm 0.011$ & 2 \\
\hline & $10^{-7}$ & $0.108 \pm 0.000$ & $0.102 \pm 0.001$ & 6 \\
\hline & $10^{-8}$ & $0.0247 \pm 0.0001$ & $0.0212 \pm 0.0002$ & 14 \\
\hline
\end{tabular}


Table S3. Cation complexation reactions to soil organic matter in the Stockholm Humic Model (SHM) ${ }^{a}$

\begin{tabular}{lccc}
\hline Reaction & $\left(\Delta z_{0}\right.$, & $\log K$ & $\Delta L K_{2}$ \\
& $\left.\Delta z_{1}\right)^{b}$ & & \\
\hline $2 \mathrm{ROH}+\mathrm{Al}^{3+} \leftrightarrow(\mathrm{RO})_{2} \mathrm{Al}^{+}+2 \mathrm{H}^{+}$ & $(-0.2,1.2)$ & -4.06 & 1.06 \\
$2 \mathrm{ROH}+\mathrm{Al}^{3+}+\mathrm{H}_{2} \mathrm{O} \leftrightarrow(\mathrm{RO})_{2} \mathrm{AlOH}+3 \mathrm{H}^{+}$ & $(-0.2,0.2)$ & -9.45 & 1.06 \\
$\mathrm{ROH}+\mathrm{Ca}^{2+} \leftrightarrow \mathrm{ROCa}+\mathrm{H}^{+}$ & $(-0.5,1.5)$ & -2.2 & 0.3 \\
$\mathrm{ROH}+\mathrm{Ag}^{+} \leftrightarrow \mathrm{ROAg}+\mathrm{H}^{+}$ & $(-0.5,0.5)$ & -2.7 & 1.68 \\
$2 \mathrm{ROH}+\mathrm{Fe}^{3+} \leftrightarrow(\mathrm{RO})_{2} \mathrm{Fe}^{+}+2 \mathrm{H}^{+}$ & $(-0.2,1.2)$ & -1.68 & 1.7 \\
$2 \mathrm{ROH}+\mathrm{Fe}^{3+}+\mathrm{H}_{2} \mathrm{O} \leftrightarrow(\mathrm{RO})_{2} \mathrm{FeOH}+3 \mathrm{H}^{+}$ & $(-0.2,0.2)$ & -4.6 & 1.7 \\
$\mathrm{ROH}+\mathrm{Mg}^{2+} \leftrightarrow \mathrm{ROMg}^{+}+\mathrm{H}^{+}$ & $(-0.5,1.5)$ & -2.5 & 0.3
\end{tabular}

${ }^{a}$ Reactions for $\mathrm{Ca}^{2+}$ and $\mathrm{Mg}^{2+}$ are from Gustafsson et al. (2007), those for $\mathrm{Fe}^{3+}$ are from Sjöstedt et al. (2013), those for $\mathrm{Al}^{3+}$ are from Gustafsson et al. (2011), and the reaction for $\mathrm{Ag}^{+}$is from this study.

${ }^{b}$ The change of charge in the $o$ - and $d$-planes respectively.

\section{References}

Gustafsson, J.P.; Persson, I.; Kleja, D.B.; van Schaik, J.W.J. Binding of iron(III) to organic soils: EXAFS spectroscopy and chemical equilibrium modeling. Environ. Sci. Technol. 2007, 41 (4), 1232-1237.

Gustafsson, J.P.; Tiberg, C.; Edkymish, A.; Kleja, D.B. Modelling lead(II) adsorption to ferrihydrite and soil organic matter. Environ. Chem. 2011, 8 (5), 485-492.

Sjöstedt, C.; Persson, I.; Hesterberg, D.; Kleja, D.B., Borg, H;, Gustafsson, J.P. Iron speciation in soft-water lakes and soils as determined by EXAFS spectroscopy and geochemical modelling. Geochim. Cosmochim. Acta 2013, 105, 172-186. 
Table S4. Data sets and optimization for silver complexation to humic and fulvic acid in the Stockholm Humic Model

\begin{tabular}{|c|c|c|c|c|c|c|}
\hline Code & Reference & $\begin{array}{l}\text { No. of data } \\
\text { points }\end{array}$ & Weight & $\log K_{\mathrm{Ag}, \mathrm{m}}$ & $\Delta L K_{2}$ & rmse \\
\hline FAg-01 & $\begin{array}{c}\text { Sikora and } \\
\text { Stevenson } \\
(1988)\end{array}$ & 23 & 1 & -2.86 & 1.6 & 0.043 \\
\hline FAg-02 & This study & 33 & 2 & -3.0 & 1.6 & 0.10 \\
\hline HAg-02 & $\begin{array}{c}\text { Sikora and } \\
\text { Stevenson } \\
(1988)\end{array}$ & 22 & 1 & -2.33 & 1.6 & 0.025 \\
\hline HAg-03 & $"$ & 23 & 1 & -2.77 & 1.6 & 0.011 \\
\hline HAg-04 & $"$ & 24 & 1 & -2.5 & 1.6 & 0.039 \\
\hline HAg-05 & $\begin{array}{c}\text { Chen et al. } \\
\text { (2012) }\end{array}$ & 24 & 1 & -2.6 & 2.0 & 0.17 \\
\hline \multirow[t]{2}{*}{ HAg-06 } & “" & 19 & $0.5^{\mathrm{a}}$ & -2.37 & 2.0 & 0.16 \\
\hline & & Average & & -2.70 & 1.68 & \\
\hline
\end{tabular}

${ }^{\mathrm{a}}$ The results for series HAg-06 (equilibrium dialysis) was more uncertain than those of HAg-05, according to the authors; hence a lower weight was given to this data set

\section{References}

Sikora F.J.; Stevenson, F.J. Silver complexation by Humic substances: Conditional stability constants and nature of reactive sites, Geoderma, 42 (3-4), 1988, 353-363.

Chen, Z.; Campbell, P. G. C.; Fortin C. Silver Binding by Humic Acid as Determined by Equilibrium IonExchange and Dialysis. J. Phys. Chem. A. 2012, 116 (25), 6532-6539. 
Table S5. A compilation of equilibrium constants for $S$ and $N$ donor ligands taken from the IUPAC Stability Constant Database (http://www.acadsoft.co.uk). Equilibrium constants given are for reactions $\mathrm{Ag}^{+}+\mathrm{L}^{n} \rightleftharpoons \operatorname{AgL}^{(1+n)}\left(K_{1}\right)$ and $\operatorname{AgL}^{(1+n)}+\mathrm{L}^{n} \rightleftharpoons$ $\operatorname{AgL}_{2}{ }^{(1+2 n)}\left(K_{2}\right)$, where $n$ is the charge of the ligand. $\log K_{1}$ for protonation reactions refer to protonation of $\mathrm{S}$ or $\mathrm{N}$ functional groups $\left(\mathrm{L}^{n}+\mathrm{H}^{+} \rightleftharpoons \mathrm{HL}^{(1+n)}\right)$. For thioethers no protonation constants exist in data base, probably because proton binding is too weak.

\section{S donor ligands}

\section{Thiols (C-SH)}

Cysteine (2-Amino-3-mercaptopropanoic acid)

$\log K_{1} \quad \log K_{2} \quad$ Reference

Silver $(I)$

11.9

Adams, N. W. H.; Kramer, J. R. Aquatic Geochem. 1999, 5, 1-11.

Proton (thiol group)

8.18

8.46

8.24 (mean)

\section{2-Mercaptoethanol}

$\log K_{1} \quad \log K_{2}$

Silver(I)

13.05
Burgarcic, Z. D.; Jancic, D. M.; Shoukry, A. A.; Shoukry, M. M. Monatsh. Chem. 2004, 135, 151-160.

Osinska-Krolicka, I.; Podsiadły, H.; Bukietyńska, K.; ZemanekZboch, M.; Nowak, D.; Suchoszek-Łukaniuk, K.; MalickaBłaszkiewicz, M. J. Inorg. Biochem. 2004, 98, 2087-2098

Rey, N. A.; Howarth, O. W.; Pereira-Maia, E. C. J. Inorg. Biochem. 2004, 98, 1151-1159.

Alderighi, L.; Gans, P.;Midollini, S.; Vacca, A. Inorg. Chim. Acta 2003, 356, 8-18.

Gharib, F.; Dogaheh, L. A. J. Eng. Chem. Data 2003, 48, 9991003.

Sharma, V. K.; Casteran, F.; Millero, F. J.; De Stefano, C. J. Solution Chem. 2002, 31, 783-792. 
9.48

9.75

9.41

9.55 (mean)
Tunaboylu, K.; Schwarzenbach, G. Helv. Chim. Acta 1971, 54, 2166-2185.

Goldberg, R.; Kishore, N.; Lennen, R. J. Phys. Chem. Ref. Data 2002, 31, 231-370.

Shoukry, M.; Shehata, M.; Hamza, M.; van Eldik, R. J. Chem. Soc., Dalton Trans. 2005, 3921-3926.

\section{Isopropyl mercaptan (2-propanethiol)}

$\begin{array}{lll}\log K_{1} & \log K_{2} & \text { Reference }\end{array}$

Silver(I)

7.05

Saxena, R. S.; Khandelwal, G. L. Electrochim. Acta 1978, 23, 953-955; in methanol/ethanol mixtures.

\section{3-Mercaptopropionic acid (Thiolactic acid)}

$\log K_{1} \quad \log K_{2}$

Reference

Silver $(I)$

12.0

Adams, N. W. H.; Kramer, J. R. Aquatic Geochem. 1999, 5, 1-11.

Proton (thiol group)

10.16 (mean)

\section{Thioethers (C-S-C)}

\section{Dimethylsulfide}

$\log K_{1} \quad \log K_{2}$

Vairavamurthy, M. A.; Goldenberg, W. S. Ouyang, S.; Khalid, S. Marine Chem. Soc. 2000, 70, 181-189.

Shoukry, M. Talanta 1989, 36, 1151-1153.

Tóth, I.; Zékány, L.; Brücher, E. Polyhedron 1984, 3, 871-877.

Silver (I)

3.7

\section{Reference}

Sigel, H.; Scheller, K. H.; Rheinberger, V. M.; Fischer, B. E. J. Chem. Soc., Dalton Trans., 1980, 1022-1028; in methanol/ethanol mixtures 


\section{Diethylsulfide}

$\log K_{1} \quad \log K_{2}$

Silver(I)

3.95

\section{Diphenylsulfide}

$\log K_{1} \quad \log K_{2}$

Silver(I)

0.48

\section{Tetrahydrothiophene}

$\log K_{1} \quad \log K_{2}$

Silver $(I)$

1.24

\section{N donor ligands}

$\begin{array}{ll}\begin{array}{ll}\text { Ammonia } \\ \log \mathbf{K}_{\mathbf{1}}\end{array} & \log \mathbf{K}_{\mathbf{2}} \\ \begin{array}{c}\text { Silver(I) } \\ 3.37\end{array} & 3.88 \\ 3.41 & 3.85 \\ 3.44 & 3.48 \\ 3.28 & 3.97 \\ 3.38 & 3.80 \text { (mean) } \\ & \\ \text { Proton } & \\ 9.25 & \end{array}$

\section{Reference}

Tilley, R. I. Aust. J. Chem. 1990, 43, 1573-1576; in methanol.

\section{Reference}

Zintl, F.; Persson, I. Inorg Chim. Acta 1987, 131, 21-26; in DMSO.

\section{Reference}

Zintl, F.; Persson, I. Inorg Chim. Acta 1987, 131, 21-26; in DMSO.

\section{Reference}

Garner, R.; Yperman, J.; Mullens, J.; van Poucke, C. L. J. Coord. Chem. 1993, 30, 151-164

Yuchi, A.; Wada, H.; Nakagawa, G. Anal. Sci. Jpn. 1985, 1, 409412.

Kołodziej, B. Can. J. Chem. 1983, 61, 383-387.

Maeda, M.; Nakagawa, G.; Biedermann, G. J. Phys. Chem. 1983, $87,121-125$ 


\begin{tabular}{|c|c|c|}
\hline $\log K_{1}$ & $\log K_{2}$ & Reference \\
\hline \multicolumn{3}{|c|}{ Silver(I) } \\
\hline 3.85 & 3.66 & Joshi, J.; Bhattacharya, P. Indian J. Chem. 1975, 13, 88. \\
\hline 3.60 & 3.46 & $\begin{array}{l}\text { Azizov, Y; Miftakhova, A.; Toropova, V. Zh. Neorg. Khim. } 1967 \\
\text { 12, } 345 .\end{array}$ \\
\hline 3.64 & 3.54 & Monk, C. B. Trans. Faraday Soc. 1951, 47, 292-297. \\
\hline 3.70 & 3.55 (mean) & \\
\hline \multicolumn{3}{|c|}{ Proton (amino group) } \\
\hline 9.69 & 2.19 & $\begin{array}{l}\text { El-Sharif, A. A. J. Solution Chem. 2006, 35, 1287-1301; El- } \\
\text { Sharif, A. A.; Shoukry, M. M. J. Coord. Chem. 2005, 58, 1401- } \\
\text { 1415; A El-Sherif, A. A.; Shoukry, M. M.; van Eldik, R. J. Chem. } \\
\text { Soc., Dalton Trans. 2003, 1425-1432. }\end{array}$ \\
\hline 9.74 & 2.44 & $\begin{array}{l}\text { Zalupski, P. R.; Jensen, M. P.; Herlinger, A. W. J. Solution } \\
\text { Chem. 2005, 34, 869-880. }\end{array}$ \\
\hline 9.69 & 2.20 & $\begin{array}{l}\text { El-Shehata, M. R.; Shoukry, M. M.; Barakat, M. H. J. Coord. } \\
\text { Chem. 2004, 57, 1369-1386; Mohamed, M. M. A. J. Coord. } \\
\text { Chem. 2003, 56, 745-759. }\end{array}$ \\
\hline 9.85 & 2.18 & $\begin{array}{l}\text { Bukietyńska, K.; Podsiadły, H.; Karwecka, Z. J. Bioinorg. Chem. } \\
\text { 2003, 84, 317-325. }\end{array}$ \\
\hline 9.77 & 2.49 & Gharib, F.; Fekri, M. H. J. Solution Chem. 2003, 32, 855-863. \\
\hline 9.76 & 3.22 (mean) & \\
\hline \multicolumn{3}{|c|}{ Glycine } \\
\hline $\log K_{1}$ & $\log K_{2}$ & Reference \\
\hline \multicolumn{3}{|c|}{ Silver(I) } \\
\hline 3.45 & 3.35 & Kiss, T.; Sovago, I.; Gergely, A. Pure Appl. Chem. 1991, 63, 597 \\
\hline 3.28 & 3.68 & Ishiguro, S.-I.; Ohtaki, H. J. Coord. Chem. 1987, 15, 237-306. \\
\hline 3.01 & 3.21 & $\begin{array}{l}\text { Isreali, M.; Pettit, L. D. J. Inorg. Nucl. Chem. 1975, 37, 999- } \\
1003 .\end{array}$ \\
\hline 3.24 & 3.72 & $\begin{array}{l}\text { van Poucke, L.; Thiers, G.; Herman, M. et al. Bull. Soc. Chim. } \\
\text { Belges 1970, 79, } 611 .\end{array}$ \\
\hline 3.22 & 3.53 & $\begin{array}{l}\text { Alner, D. J.; Lansbury, R. C.; Smeeth, A. G. J. Chem. Soc. A } \\
\text { 1968, 417-412. }\end{array}$ \\
\hline 3.24 & 3.50 (mean) & \\
\hline
\end{tabular}


Proton (amino group)

$9.60 \quad 2.33$

El-Sharif, A. A. J. Solution Chem. 2006, 35, 1287-1301; ElSharif, A. A.; Shoukry, M. M. J. Coord. Chem. 2005, 58, 14011415.

$9.58 \quad 2.34$

Altun, Y.; Köseglu, F. J. Solution Chem. 2005, 34, 213-231.

$9.58 \quad 2.37$

Altun, Y.; Köseglu, F. J. Solution Chem. 2005, 34, 869-231.

$9.61 \quad 2.32$

El-Shehata, M. R.; Shoukry, M. M.; Barakat, M. H. J. Coord. Chem. 2004, 57, 1369-1386.

$9.59 \quad 2.34$ (mean) 

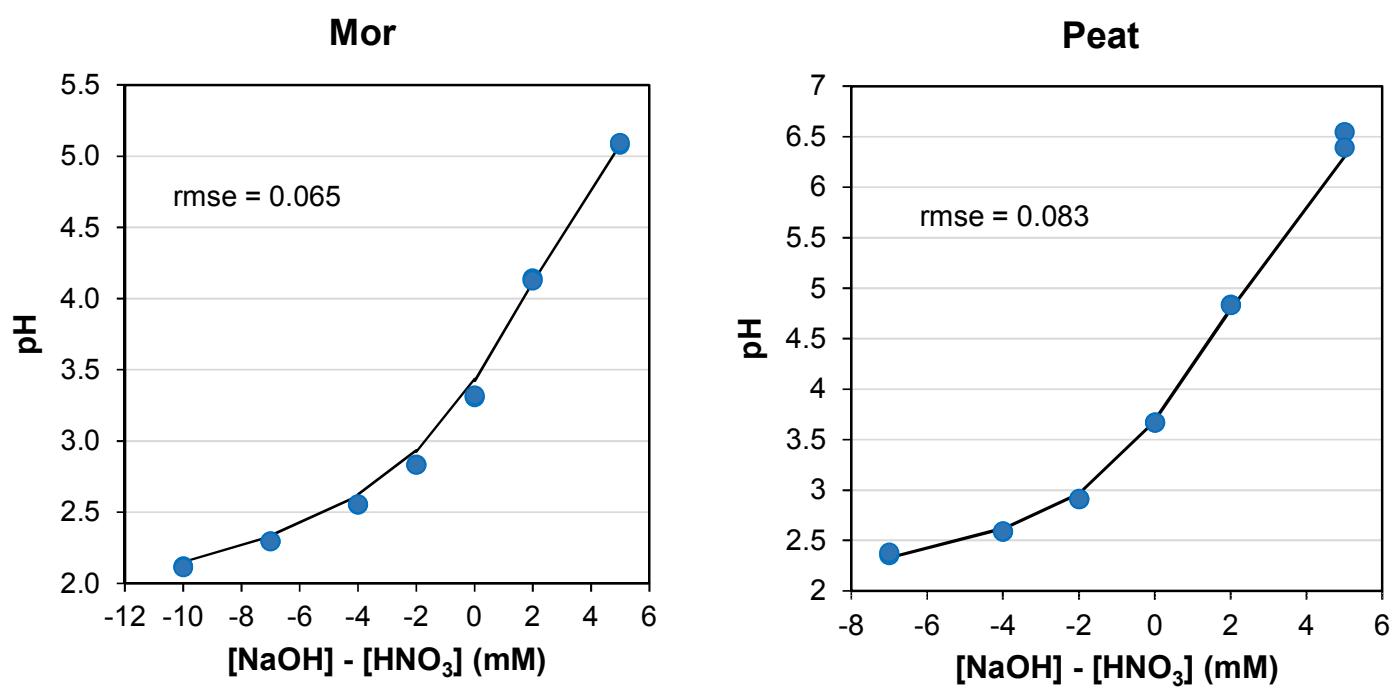

Figure S1. The $\mathrm{pH}$ as a function of the base - acid added (as $\mathrm{NaOH}$ or as $\mathrm{HNO}_{3}$ ) for the systems under study. The points are observations, and the lines are fits after optimization of the concentration of active humic and fulvic acid (rsme = root-mean-square-error). 

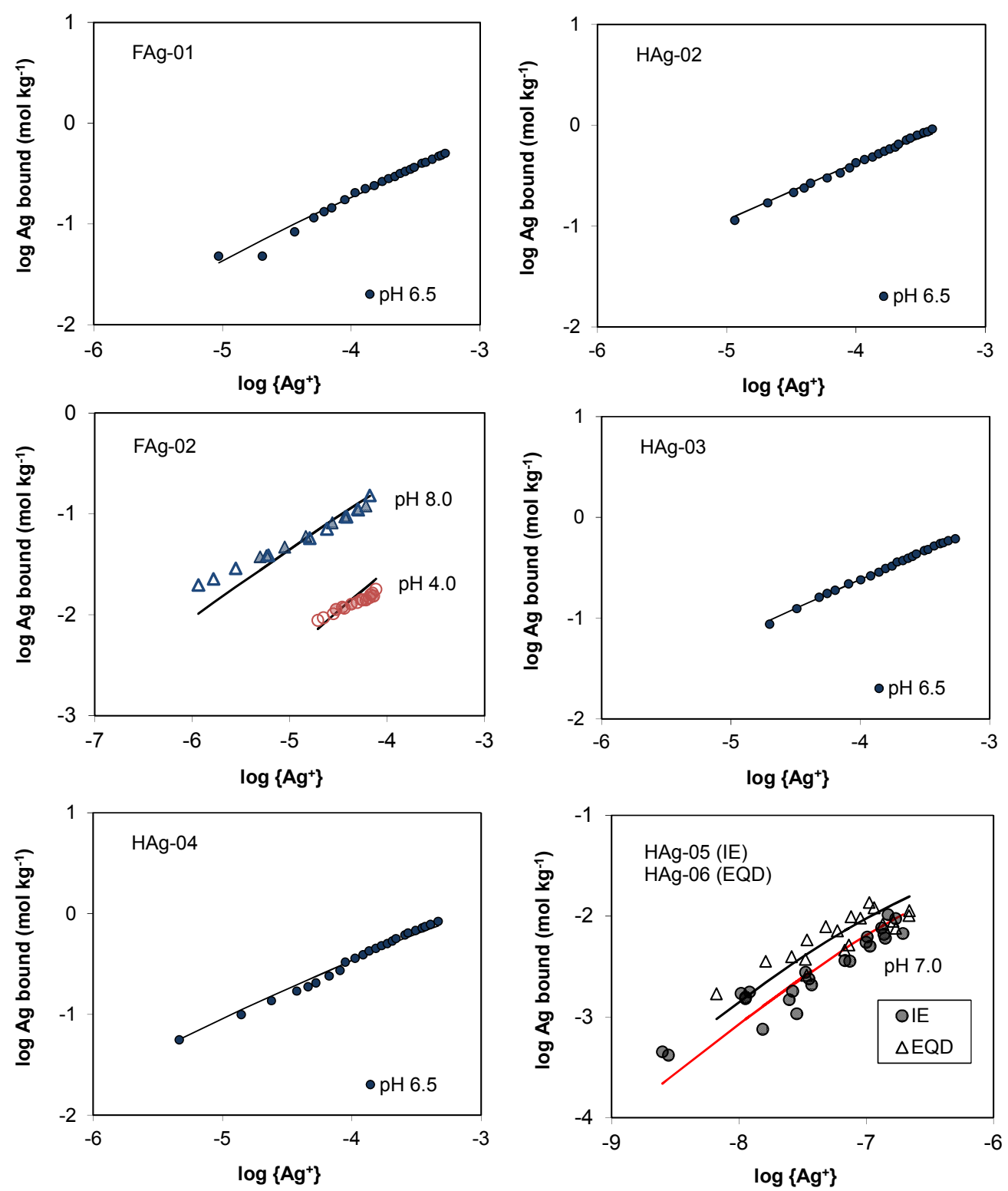

Figure S2. Experimental data (symbols) and model fits (lines) for isolated fulvic and humic acids using binding parameters in Table S4. 

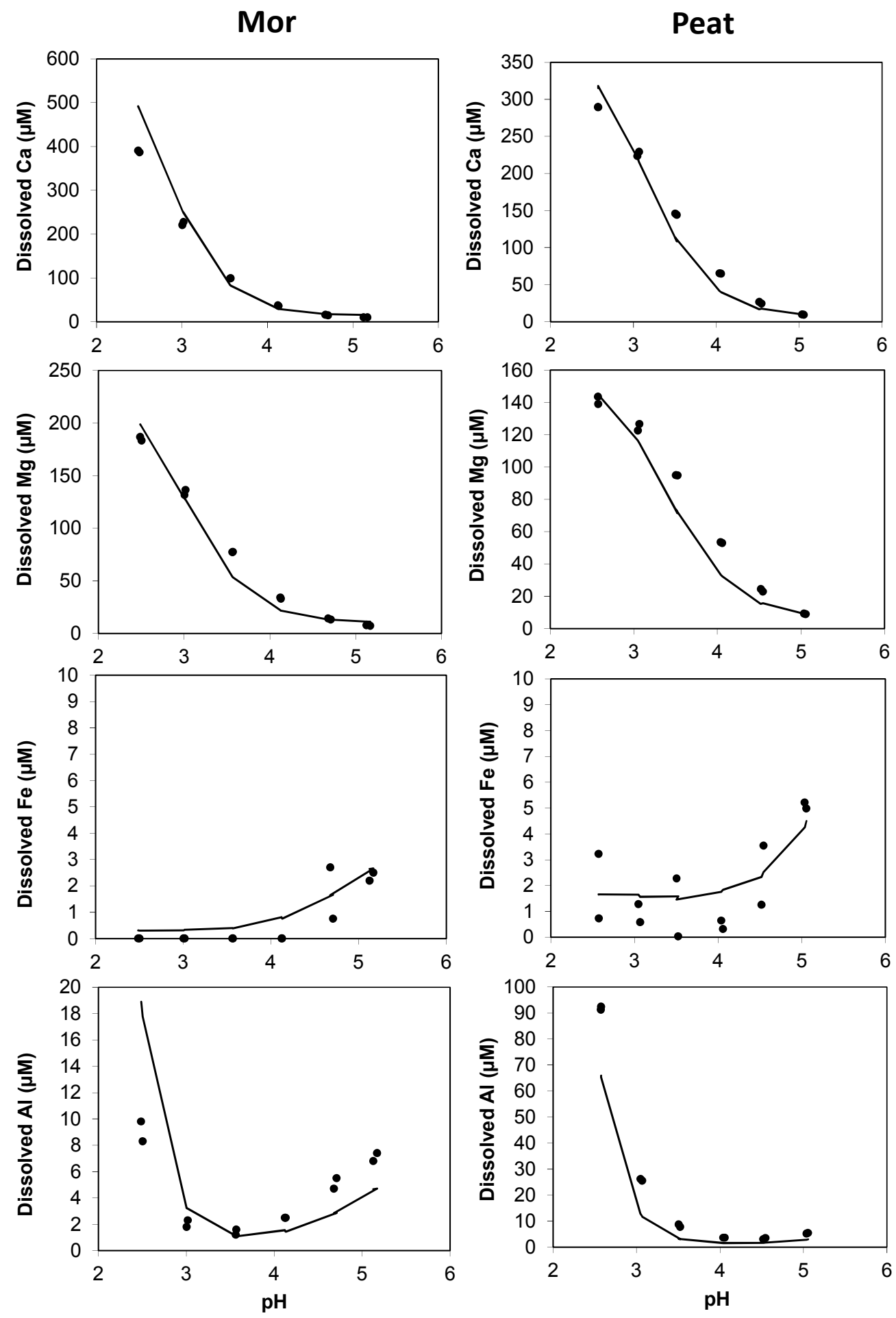

Figure S3. Measured (filled circles) and modeled (lines) solubility of $\mathrm{Ca}, \mathrm{Mg}, \mathrm{Fe}$ and $\mathrm{Al}$ in the mor and peat suspensions with a total Ag concentration of $10 \mu \mathrm{M}$. Generic proton and metal binding parameters were used in the simulations (Table S3). 


\section{Conditional equilibrium constants}

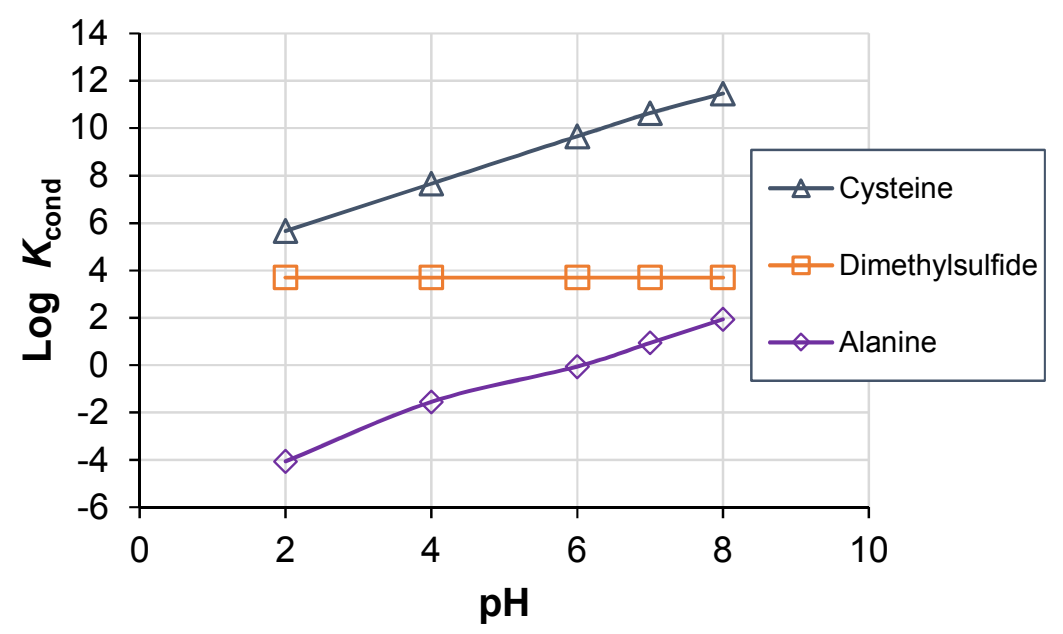

Figure S4. Conditional constants $\left(K_{\text {cond }}\right)$ for silver(I) binding by cysteine (thiol), dimethylsulfide (thioether) and alanine (amine). $K_{\text {cond }}=\left[\mathrm{AgL}^{(1+\mathrm{n})}\right] /\left(\left[\mathrm{Ag}^{+}\right]\left[\mathrm{L}_{\text {tot }}\right]\right)$, where $\mathrm{AgL}{ }^{(1+n)}$ is silver(I) bound by the ligand, $\mathrm{Ag}^{+}$is free silver ions, and $\mathrm{L}_{\text {tot }}$ is total concentration of ligand. In the calculations it was assumed that $\left[\mathrm{L}_{\mathrm{tot}}\right]>>\left[\mathrm{AgL}^{(1+\mathrm{n})}\right]$ and that protonation of the thioether group could be ignored. Constants used in the calculations are given in Table S5 (mean values, if available). No equilibrium constants for disulfides are available in the IUPAC data base, indicating very low affinity for silver(I) by this type of groups. 

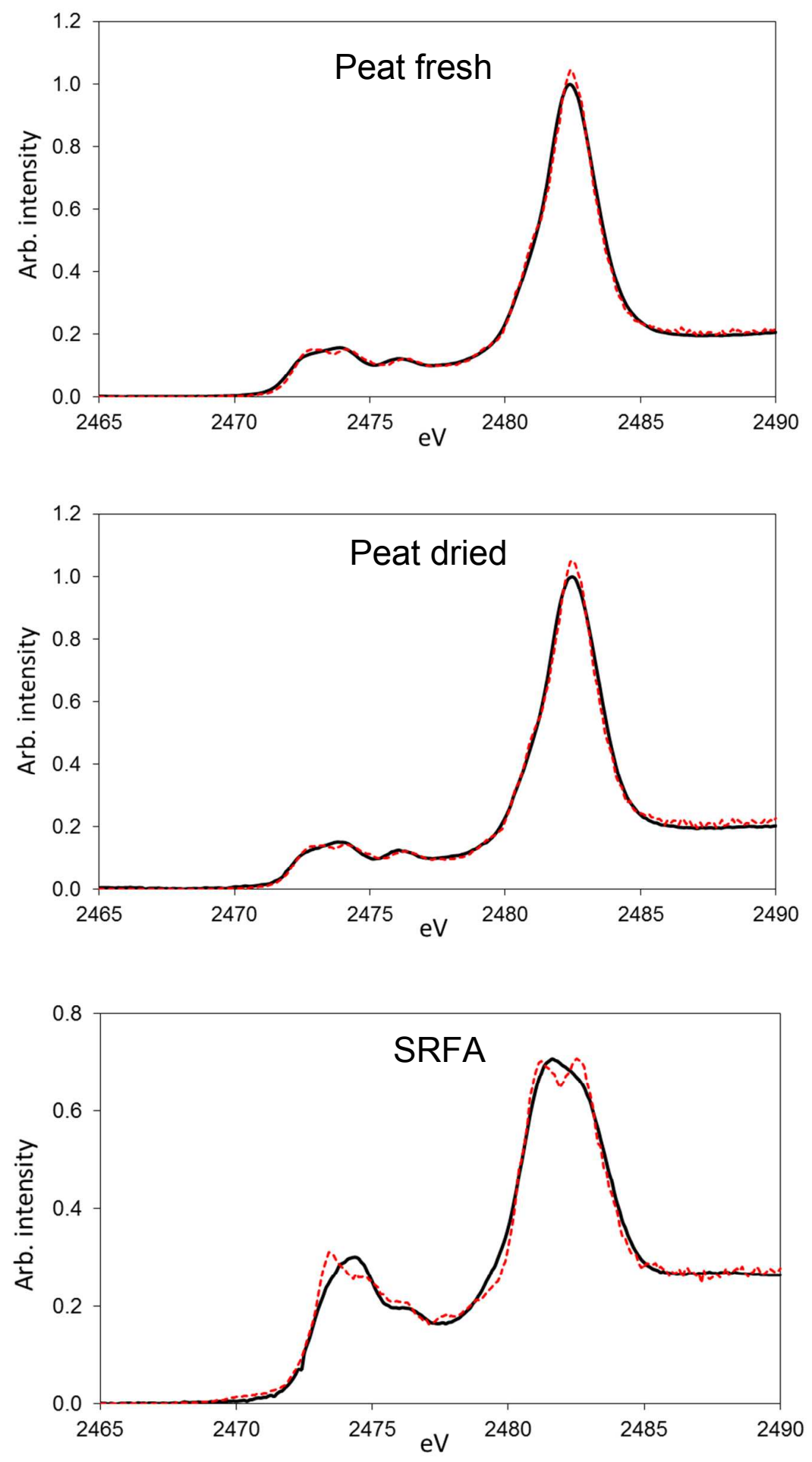

Figure S5. Sulfur $K$-edge XANES spectra of untreated (fresh) and air dried peat sample and the IHSS Suwannee River fulvic acid I (SRFA) standard. Black solid lines are measured data and red broken lines are model fits using the method described by Almkvist et al. (2010). 

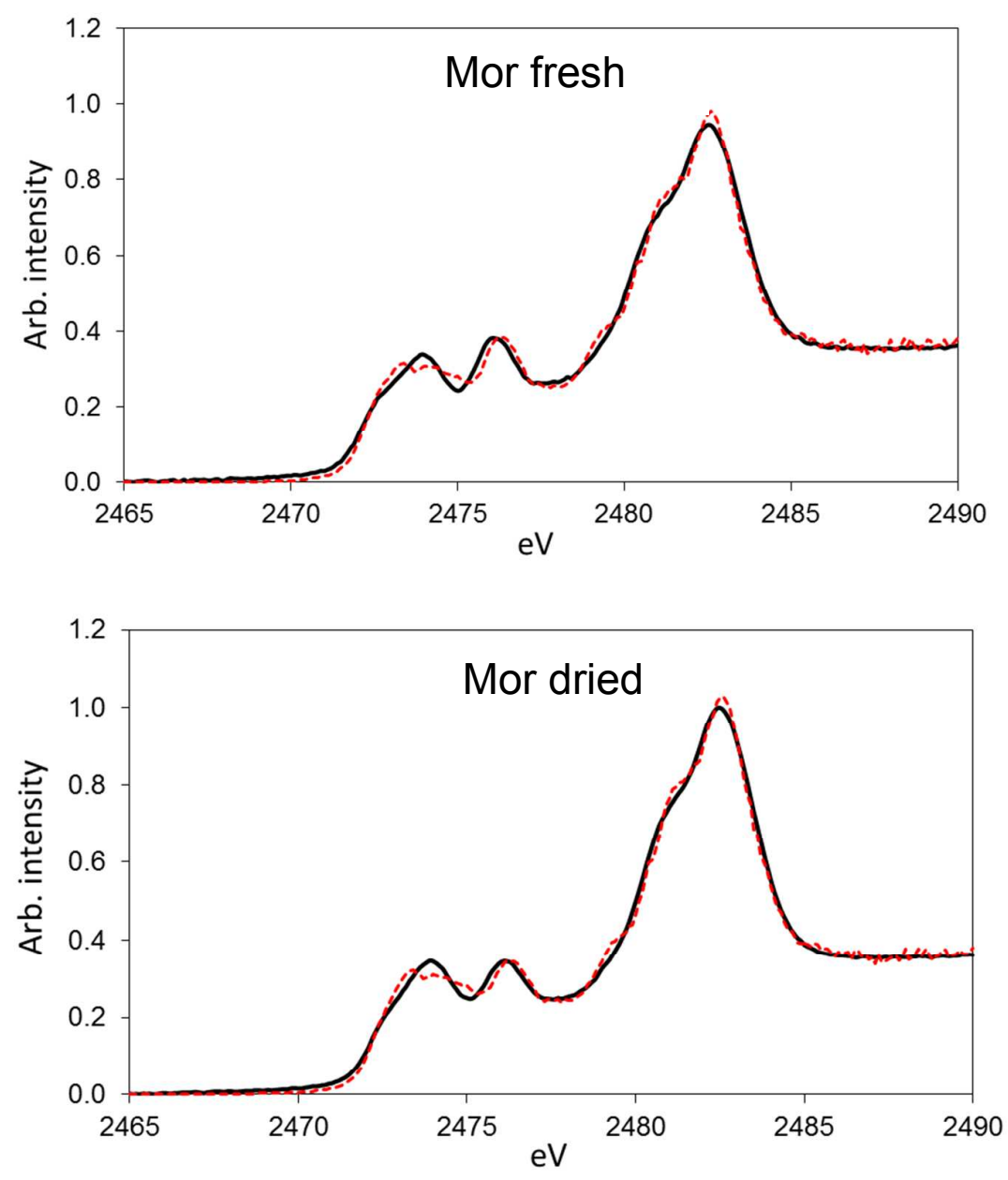

Figure S5 continued. Sulfur $K$-edge XANES spectra of untreated (fresh) and air dried mor sample. Black solid lines are measured data and red broken lines are model fits using the method described by Almkvist et al. (2010).

\section{Reference}

Almkvist, G.; Boye, K.; Persson, I. K Edge XANES Analysis of Sulfur Compounds - An Investigation of the Relative Intensities Using Internal Calibration. J. Synchrotron Rad. 2010, 17, 683-688. 

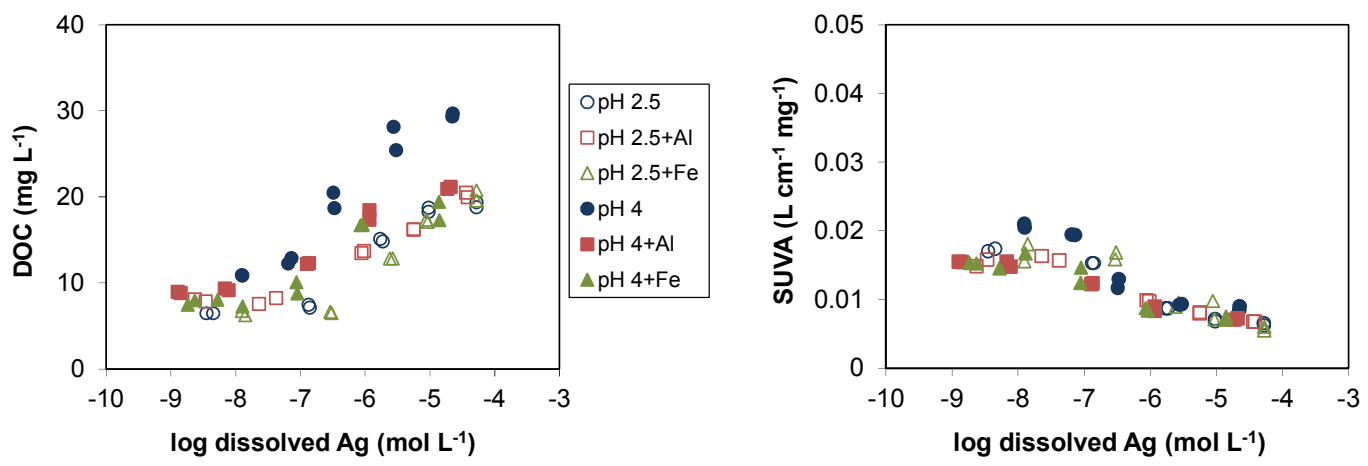

Figure S6. Concentrations of DOC and specific UV absorbance at $254 \mathrm{~nm}$ (SUVA) in the silver binding experiments with the peat sample at $\mathrm{pH} 2.5$ and 4.0, with and without additions of $\mathrm{Al}(\mathrm{III})$ or $\mathrm{Fe}(\mathrm{III})$ salts. 